\title{
Ten
}

\section{CONCEPTS OF GOD'S NATURE AND EXISTENCE}

Theism is belief in God. Theistic Cosmology says that God caused the Big Bang, that God created the world. To understand and evaluate Theistic Cosmology, many questions must be considered: What does "God" mean? What does it mean to say that God caused the Big Bang? What evidences support Theistic Cosmology? Can Theism be defended against profound objections to it? Does order and design in the universe as disclosed by Anthropic Astrophysics indicate that God exists. Does cosmic contingency or dependence provide strong evidence for the reality of God?

Before examining the evidence, we must first consider the concept of God. Debating the existence or non-existence of flying warthogs would be inane until we first know what "flying warthogs" means. (They are the US Air Force's A10 fighter-bombers.) Debating the existence or non-existence of God is equally foolish unless we first know what "God" means. Most theists are also atheists; they are convinced that God, in many meanings of the term, does not exist. Early Christians, for example, were branded as atheists and persecuted by the Romans because they denied the existence of the finite, fickle, immoral, anthropomorphic gods of the Greco-Roman pantheon.

\section{Two Concepts of God's Nature: Classical and Process Theology}

"God" has innumerable meanings. We cannot discuss them all, but we will consider at least two very different but cosmologically relevant concepts of the nature of God-Classical Supernaturalism and a modified version of Process Theism. These concepts presently contend for acceptance by thoughtful theistic believers, and we must choose between them as intelligently as possible. All Theists believe that God exists, but not all Theists believe in the same God. Who is God? What is God like? How is God related to the world? Classical Theism offers one answer and Process Theism another. Prior to the twentieth century, Classical Theism was the dominant view of God among professional theologians in traditional Catholic, Protestant, Jewish, and Islamic monotheism.

Process Theism was anticipated by earlier thinkers, but it was developed primarily in the twentieth century by Alfred North Whitehead and Charles Hartshorne. Henri Bergson also made important contributions. Numerous philosophers and theologians such as Robert L. Calhoun, Nels F. S. Ferré, John B. Cobb, Jr., Daniel Day Williams, Schubert M. Ogden, David R. Griffin, John A. T. Robinson, Robert C. Neville, Marjorie H. Suchocki, Lewis S. Ford, Bowman L. Clarke, Sally McFague, Holmes Rolston, III, Arthur Peacocke, John Polkinghorn, Ian Barbour, Rem B. Edwards, and many others were deeply 
influenced by Whitehead and Hartshorne and made, or are still making, their own significant contributions to this theological perspective, even when they disagree with or about some of its features. Many contemporary religious thinkers who accept the essential point that God is in process do not consider themselves to be Process Theologians because they reject certain emphases of mainstream process thinkers like Alfred North Whitehead, Charles Hartshorne, John B. Cobb, Jr., and David R. Griffin. In this book, "Process Theology" is broadly understood to include all who ascribe to God a temporalistic or processing nature, and much room is allowed for honest disagreement on details among Process Theologians themselves. The version of Process Theism defended here is significantly modified to allow for God's ability to create our universe out of nothing, God's voluntary self-limitation in creating co-creative creatures, God's ability to experience passively the present self-creativity of temporal occasions, and God ability to influence events as they occur in time.

Process Theology is a rational or philosophical theology. As such, it aspires to satisfy credible criteria for a plausible rational theology. (1) It must be logically consistent, a chronic shortcoming of Classical Theology, say Process Theologians; and it must satisfy other criteria of rational explanatory adequacy like coherence, simplicity, comprehensiveness, clarity, and conformity with experience. The concept of "experience" is broadly construed; it includes sensory experience as well as religious experience, aesthetic experience, and moral, logical, religious, and mathematical intuitive experience.

(2) It must explicate the ideal of perfect excellence or supreme worshipfulness expressed in St. Anselm's concept of "that being than whom none greater can be conceived." "Divine perfection" is a valuational or axiological concept as well as a metaphysical notion. Developing a concept of God as a perfect being is not an empirical project. Rational theology allows plenty of room for honest intellectual doubt, disagreement, and growth; but a start must be made somewhere. Until thoughtful religious people reach agreement about what is ultimately admirable, they must simply agree to disagree about some, but not all, attributes of divine perfection. Faithfulness to the originators of Process Theology like Whitehead and Hartshorne must often yield to our most profound sensitivities about supreme worshipfulness.

(3) A rational theology must also be compatible with, that is, it must not be falsified by, the structure and contents of the world that natural science discloses. Science does not dictate rational theology, but it rules out many familiar religious beliefs, especially cosmological convictions, as unviable and untenable. For example, rational persons cannot accept a literal six days of creation in the face of astronomy and paleontology, cannot reject evolution in the face of biology, and cannot affirm rigid and universal determinism in the face of quantum physics. A rational theology cannot affirm that Adam and Eve once existed in an idyllic Garden of Eden, or that anything of any theological importance depends upon their having so existed. It cannot affirm that death originated as a consequence of human misbehavior, since organisms were dying for eons of 
time before human beings evolved. Being compatible with natural science is not the same as being proved by natural science. Philosophical theology aspires to proof by reason or philosophy in a very broad sense, but not by empirical or sensory inquiry alone.

(4) A rational theology must also provide a plausible and coherent account of the immediate and the ultimate meaning and value of human life, indeed of all life. This account also must be firmly grounded in and compatible with scientific knowledge and critical rational reflection, as well as with our most profound religious, moral, and aesthetic sensitivities.

Classical and Process Theologians usually agree that they are trying their best to conceive of divine perfection and to answer the question of the meaning of human existence. Let us begin with divine perfection. What would God have to be like to be supremely worthy of human worship, love, service, and devotion? St. Anselm characterized God as "That Being than whom none greater can be conceived." By "greater" he meant "better." This understanding of divine perfection is at the heart of the Ontological Argument, through which Anselm hoped to persuade all rational persons of God's existence. Anselm argued that if we truly understand the meaning of the concept of God, we cannot deny God's existence without contradicting ourselves, that is, without affirming that a Divine Being who could not not exist might nevertheless not exist.' Both Classical and Process Theologians try to conceive of a God who exemplifies all desirable attributes or perfections, including necessary existence, and who is truly worthy of being loved with all our hearts, souls, minds and strength. To show that this can be done, we must do it; and doing it shows that it can be done!

Classical Theism began with Philo, a Jewish theologian living in Alexandria, Egypt in the first century A.D. The second through fifth-century Christian church fathers were profoundly influenced by Philo's project of combining the Greek philosophers' ideal of divine perfection with that of Biblical authors. From the time of the Eleatics, Greek philosophers conceived of God as simple, undifferentiated, unitary, passionless, and timeless Being. The attribute of rationality was often thrown into the bargain. Biblical writers, by contrast, conceived of God as both transcendent and immanent, as unitary but complex, as having real feelings and volitions as well as rationality, knowledge, or wisdom, as acting temporally and historically upon and within the world and its inhabitants, and as responding in time to events within nature and human history. Classical Theists fused Hellenic with Hebraic ideals of Divine perfection, thereby producing an unstable theological synthesis riddled with paradox and unintelligibility.

The Classical synthesis of incompatible ideals of Divine perfection lasted for almost two thousand years and is still going strong. Classical Theism is not identical with popular Judaism or Christianity, which are usually much closer to Biblical religion than to "big name" Classical Theologians like Augustine, Anselm, Aquinas, Moses Maimonides, Martin Luther, and John Calvin. ${ }^{2}$ 
The Classical understanding of God dominated early Christian and Medieval theology, and it still prevails in Roman Catholicism. It has been almost as influential among Protestants. To illustrate, consider the following contrast between Process Theology and Classical Theism as it was expressed by reformed Protestants in the highly influential "Westminster Confession" of 1647. ${ }^{3}$ Though it is rational rather than revealed theology, Process Theism is actually much closer in many respects to Biblical and popular religion than is Classical Theism. "The Westminster Confession of Faith" identified the following central metaphysical attributes of God.

There is but one only living and true God, who is infinite in being and perfection, a most pure spirit, invisible, without body, parts, or passions, immutable, immense, eternal,...almighty.... ${ }^{4}$

Let us reflect upon this lists of divine attributes, though not exactly in this order.

\section{A. Infinite in Being and Perfection}

Plato's Principle of Plenitude dominated Classical Theology's ideal of divine perfection, but the fullness was in God, not in creation, as previously noted. God's perfection consists in infinite being, in knowing, but not necessarily in creating or actualizing all possibilities, an infinite number of them. In himself, God is pure being, pure actuality, an actus purus, in whom there is no becoming, and no unactualized potentialities. Just why this did not translate into the belief that God has actually created all possible worlds is unclear. Plenitude of Divine Being merged with plenitude of creation would imply that everything that God could possibly create was actually created from eternity, including all possible universes. Classical Theologians believed only that every mutually compatible niche in the great chain of being was filled in God's one universe. God's fullness and self-sufficiency in himself, not in creation, makes God perfect and supremely worthy of worship, service, and devotion, according to Classical Theology.

For many good reasons, Process Theology does not accept the Principle of Plenitude, either in God's Being or in God's Creating. The process understanding of divine perfection includes both Divine Being and Divine Becoming. It recognizes that choices must be made between things that could be created separately but not together, that infinity cannot be exhausted, used up, or fully actualized either timelessly all at once, or successively, and that divine creativity is interminable. It acknowledges that some possible worlds are too horrible, trivial, or boring to be created by a loving, morally upstanding, and aesthetically sensitive God. All Divine attributes in their integrated wholeness and togetherness are integral to God's perfection. 
Process Theology completely rethinks all the old problems of theology in light of the hypothesis that aspects of both process or change and permanence or constancy are in God. Divinity includes both an unchanging timeless dimension, God's Primordial Nature, and a changing temporal dimension, God's Consequent Nature. In Classical Theology, God is only being; but in Process Theology, God is both being and becoming.

God's everlasting and changeless Primordial Nature includes God's necessary existence and God's eternal vision of possibilities for creation. Plato's ideal forms are relocated in the mind of God. Whitehead called them "eternal objects." Possibilities as such are empty systemic abstractions that have no definiteness and significance to and for themselves and are deficient in definiteness even for others. Eternal objects are not the ultimate, independently existing, causally productive, concrete realities that Plato thought them to be. They lack the definiteness, concreteness, and power of existing actualities in physical space and time; and they are devoid of intrinsic subjectivity-the immediacy of self-awareness, self-creation, and self-enjoyment possessed by concretely existing individual centers of conscious experience, activity, and valuation like God, ourselves, and most if not all non-human animals and living things. Process thinkers disagree about the full extent of God's knowledge of possibilities; but we need not settle that question here.

Whitehead probably included little more than God's envisionment of possibilities, eternal objects, and their relevance to possible worlds, in God's Primordial Nature; but for many good reasons other process thinkers, Hartshorne and Cobb especially, have considerably enriched the notion. The Primordial Nature also includes God's necessary existence, necessary creativity, and God's enduring and essential general capacities for knowing everything that actually exists and that might possibly exist (omniscience), for loving all concrete actualities (omniloving), and for creatively influencing (omnipotence) and being influenced by (omnipresence and omnisensitivity) every actual entity. God's unchanging and ever dependable love, compassion, and all-around moral virtue or righteousness belong to the Primordial Nature. The abstract essence of God, the Primordial Nature, is deficient in actuality; but the fullness of God includes both a Primordial and a Consequent nature. The two are separable in thought, but not in reality.

The Primordial Nature of God transcends every particular cosmic epoch or created universe while existing necessarily in relation to all particular epochs and universes and what transpires within them. Critics of Process Theology like Mark W. Worthing ${ }^{5}$ who regard the God of Process Theology as completely immanent in our finite cosmos totally ignore the everlasting, necessary, and transcendent Primordial Nature of God. Without a Primordial Nature, a contingent and purely immanent God would die either the heat death or the Big Crunch death of our universe; ${ }^{6}$ but Process Theology affirms that God's Primordial essence transcends and endures before, through, and after all created 
worlds. So does God's Consequent Nature as such if God has been infinitely creative in innumerable worlds.

In the Consequent Nature, God's transcendent and everlasting abstract capacities are concretized in relation to actual worlds. The Consequent Nature is God's actual creation of and interaction with individuals in space, time, and history. God comes to know, love, influence, and be influenced by all actual entities as they concretely exist and become within spacetime. God's experiences of successive events in time are themselves successive and thus temporal.

God's experience of value is enriched by every concrete value realized in all actual worlds; all values created by and within all creatures are taken into God's Consequent Nature and saved there forever. God is the supreme valuer of every intrinsic value actualized within every world, including our own. God experiences all values (and disvalues) realized by concretely existing spatiotemporal individuals; and after they have perished to themselves, God remembers and profoundly cherishes (or deplores) them forever. Existing events possess their own present moment of relative independence and immediacy of self-enjoyment and self-creativity. As temporal occasions perish to themselves, they achieve permanent being or "objective immortality" in God's infallible memory. God's Consequent Nature continuously assimilates and treasures the ongoing order and concreteness of all spatiotemporal actualities.

God is constantly being created, says Process Theology, but not the necessary existence or the abstract essence of God, both of which belong to the Primordial Nature. The Consequent Nature consists of the full actuality of God's decisions about, experiences of, interactions with, and responses to concretely existing creatures as they are constantly being created. God exists necessarily, but the full actuality of Divinity is contingent, depending in part upon God's own freely creative acts and in part upon free decisions made by God's creatures. God affects the world, but the world also affects God, for better or for worse. God is affected by values and disvalues realized in all of creation.

An unsolved problem remains after we realize that our lives are intrinsic ends and that their significance does not depend upon their contributions to some far distant future Grand Enduring Objective. The problem is that all temporal goods, including those that are intrinsic, are transient, fleeting, and ephemeral. We ourselves, and the very best moments of our lives, perish in time. Through memory, we can recover traces of our most precious moments; but eventually we die, and our memories die with us. Traces of the concrete values realized in our lives may remain in the memories and even in the genes of others; but eventually they also die with their memories and their genetic endowment. Some day the human race will perish-after thousands of years perhaps if we are lucky and are good stewards of the earth, which we do not seem to be. Will no trace of our worth ultimately remain? Bertrand Russell thought not, and the idea filled him with profound pessimism. In "A Free Man's Worship," he wrote: 
All the labor of the ages, all the devotion, all the inspiration, all the noonday brightness of human genius is destined to extinction in the vast death of the solar system, and that the whole temple of Man's achievement must inevitably be buried beneath the debris of a universe in ruins-all these things, if not quite beyond dispute, are yet so nearly certain that no philosophy which rejects them can hope to stand.?

Process Theology offers an attractive solution to the problem of the transience of all created goods-the Doctrine of Contributionism. All created values are ultimately contributed to God, who remembers and cherishes them everlastingly. All created events and values become objectively immortal in God. ${ }^{8}$ Some, but not all, Process Theologians also affirm subjective immortality-the survival after death of individual subjects in the alternate spacetime system of Heaven.

Many theologians assume otherwise, but a traditional Christian Heaven does not solve the problem of the transience of created values. As my friend Tom Dicken indicates, "Immortality offers a continuing creation of value, not a conservation of value." We can make little or no sense of an utterly spaceless and timeless Heaven where everyone is disembodied and nothing ever happens; but if spatiotemporal events transpire in Heaven, they too perish to themselves.

Time, whether Heavenly or worldly, is indeed a perpetual creation and rebirth of events; but it is also a "perpetual perishing," as John Locke put it. Unless the concrete values realized in both worldly and Heavenly events are known fully and preserved forever by God, ultimately they are lost forever; but in God's Consequent Nature there is no ultimate loss. God gives the intrinsic worth of all creatures objective immortality and intrinsically valuates them without end. God is the supreme intrinsic valuer of all intrinsic, extrinsic, and systemic values in all actual worlds.

The objective immortality of all creatures and created values in God are not just additional remote Enduring Grand Objectives. Enduring Grand Objectives are ends in themselves and have intrinsic worth, supposedly; but the means to them do not; and we are the intrinsically worthless means! But, says Process Theology, God values creatures like us as ends, not merely as means. According to the Final Anthropic Principle, the Omega Point has intrinsic worth; and we are significant only as means to that terminal condition. In traditional Christian theology, this life is but a miserable pilgrimage to what is truly worthwhile-pie in the sky by and by. Enduring Grand Objective theories degrade our lives here and now into extrinsic or systemic goods; but Process Theology affirms that the intrinsic worth of our lives here and now is ultimately contributed to God, who cherishes us and every living creature forever.

God's love is not limited to humanity; it extends to every experiencing subject that ever exists. All animals, not just human ones, and not just members of contemporary species, are included. Panexperientialism or panpsychism, to 
which some process thinkers subscribe, says that all existing individuals including sub-atomic particles (but not aggregates like rocks) are experiencing subjects having some degree of intrinsic worth. We do not have to decide that issue here. The essential thing is that intrinsic values actualized in all presently living creatures, in our hominid ancestors, and in every extinct individual and species that ever lived, are not lost. They exist forever in God. Past values are lost to themselves and to our present selves for the most part, but no achieved goodness is ever lost to God.

God does not timelessly actualize all possibilities, that is, all possible individuals, their qualities, and relations, according to Process Theology. God alone could know it, but an infinite number of possibilities may have been actualized in an infinite number of universes within God's supercosmic past or present if God is infinitely creative. Superspacetime may be an attribute of God! Yet, infinite possibilities for further creativity always remain for the supercosmic future of an infinitely creative God. Neither God nor man can use up infinity, not even in an infinite amount of time.

\section{B. A Most Pure Spirit, Invisible, Without Body}

Erroneously, Classical Theologians often identified the biblical notion of "spirit" with the Platonic/Neoplatonic/Cartesian notion of an immaterial and potentially disembodied mind or soul. According to Plato, immaterial, nonspatial human minds are temporary prisoners in their spatially extended bodies. Platonic immortality encompassed both existence before birth and survival after death for disembodied, nonspatial, immaterial souls.

By contrast, in the Biblical tradition, body and spirit are inseparably unified; and survival after death takes the form of the resurrection of a dramatically transformed body, relocated ultimately in an alternate spacetime system, but never completely non-spatial or immaterial. In the earliest centuries of the Christian era, Platonic mind/matter dualism spilled over into Classical Theology. God himself was understood to be incorporeal or "without body" as the "Westminster Confession" put it. Since incorporeal things are imperceptible, God's invisibility indicated incorporeality to Classical Theologians.

In Biblical, creedal, and popular religion, God, the invisible spirit, is embodied, at least metaphorically. God has hands, feet, a face, right and left sides, a backside, and such. God is pictured as a large, humanoid, white or tawny skinned, blue-eyed, gray-bearded male who sits on a white throne, wears a jeweled crown, and has a string of lieutenants on each hand, the right hand (where Jesus sits) being most favored.

Neither Classical Theology nor Process Theology takes this physical humanoid imagery literally, however, and even this has a Biblical basis. The Second Commandment in the Old Testament prohibits making graven images or likenesses for religious purposes of anything (including humankind) that is 
in heaven above, the earth beneatth, or the water under the earth (Exodus 20:4). Implicit in the Second Commandment is a profound metaphysical insight: God's form, whether physical or not, "cannot be represented by any familiar finite physical forms. God is infinite be:ing, not physically finite and humanoid being. Judaism and Islam allow no representative art as aids to worship and thus generally take the Second Commaandment much more seriously than Christianity, except for the early Christiam iconoclasts.

For Classical Theologians, thuman beings are made in the spiritual, not the physical, image of God because an incorporeal being has no physical image. Process Theologians repudiate mind/matter dualism and insist that the mental and spiritual aspects of all actual "entities, including God, are always embodied. God does not literally have humaunoid hands, feet, eyes, face, and so forth; but, contrary to Classical Theology, P'rocess Theologians think that God has a body and is not totally incorporeal. Gocd's body is the universe, or at least some world or worlds, perhaps even infinite "Superspacetime itself. God may be embodied in infinitely many actual worlds fffor all we know. God's body or bodies belong to the Consequent Nature; but God's Primordial Nature transcends and persists through all embodiments in all sipatiotemporal phases of all the worlds God's "hands" have made.

God's spirituality and mentuality are related to the world as our own spiritual and mental dimensions are melated to our bodies. If we really understood that, the analogy would be muckm more illuminating! In our universe, organic wholes have both an internal amd an external unity plus properties that are influenced by but not reducible tho the sums of their component parts. Protons are influenced by but not reducibole to their constituent quarks; and the same is true of atoms in relation to their mrotons, neutrons, and electrons, of molecules in relation to their component attoms, of living cells in relation to their molecules, of brain-consciousness as melated to brain cells, and of Divine consciousness as related to the whole of ucreation. In some mysterious way, our cells, organs, and bodily processes afffect our conscious experiences and activities. Our conscious experiences and anctivities as embodied in our brains also affect our other bodily processes, organus, and cells without violating any natural laws.

We are to God as our cells : are to us, and God is to the world as our consciousness is to our bodies, but with important differences as well as similarities. The well-or-ill-being of ourr cells, especially our brain cells and brain waves, affect and are affected by our consciousness; ${ }^{10}$ and God affects and is affected by the well or ill being off our conscious experiences and activities. The important differences are: (1) hurman consciousness has only a limited sensitivity to bodily events, but God is conmpletely attuned and responsive to all worldly events, and (2) we are largely unnaware of events external to ourselves, but everything is internal to God, who misses nothing. Both we and God are embodied; and just as our stream of comsciousness, the dominant society of events in our bodies, can affect the rest of (rour bodies without violating any natural laws, 
so can God affect the world. No actual beings are purely spiritual, invisible, incorporeal, and disembodied. God is literally the all-inclusive spatiotemporal reality in whom we live and move and have our being-and our becoming.

Religiously, God's ability to affect the world, to influence and communicate with us creatures without overwhelming our freedom, is just as important as God's ability to be affected by the world. Just how, in technical metaphysical terms, this is possible may be and is debated extensively; ${ }^{11}$ but that it is so is indispensable to our concept of that being than whom none greater can be conceived. The details of just how this is possible need not be resolved here.

\section{Immense}

To have a body is to be spatially extended. As Descartes noted, all bodies are extended; this is what being a body or being physical means. Spatiality is the defining characteristic of embodiment. Paradoxically, despite its claim that God is without body, Classical Theology affirmed that God is immense or omnipresent. These words intimate spatiality in a Being who supposedly exemplifies no spatiality or corporeality at all. "The Westminster Confession" affirms the immensity of God based on I. Kings 8:27, which says that Heaven and the highest Heaven cannot hold God, and on Jeremiah 23:23-24, which says that God is not far off but fills Heaven and earth. Other Biblical passages also affirm the omnipresence of God. Psalms 139:7-10 presents God as an inescapable presence who cannot be evaded in Heaven, Hell, or the uttermost parts of the sea; and St. Paul affirmed, according to Acts 17:28, that God is the being in whom we live and move and have our being.

Classical Theology embraced the paradox of God's spatiality with one breath (immense, omnipresent) and denied it with the next (pure spirit, incorporeal); but how can a being who is nowhere be everywhere? How can a being who is everywhere be nowhere? With no evasiveness, Process Theology attributes both spatiality and temporality to God. God's Consequent Nature is that most inclusive spatiotemporal reality within which or whom we live and move and have our becoming. Localized moral agents like ourselves are only finite parts of our local spacetime system; but God is the all-inclusive ultimate reality.

A temporally ordered looseness of fit obtains between God, the whole of all inclusive Superspacetime, and our spacetime. This looseness allows room for creaturely freedom and creativity. Individual events within the whole of God's reality, for example, those composing human streams of consciousness, enjoy a fleeting moment of relative independence, originality, and creative self-synthesis (to which God is passively sensitive) before they perish to themselves and gain objective immortality within God. This slight departure from process orthodoxy will be better explained in what follows.

God always and necessarily has a body, some body, because God is always and necessarily a creative, loving, social being who creates others to love. 
If God is embodied, can we see God? Yes, in a sense; but we cannot see all of God's body, the whole of our spacetime, or the whole of God's Superspacetime; and we cannot see the transcendent Divine Primordial Nature or the privacy of God's own consciousness. But every time we look into another persons eyes, or behold the good earth, or gaze at the wondrous starry Heavens above, we see some of the components of God's immanent Consequent Nature. All things are divine, even the mundane, though most of us do not realize this. Appropriately qualified, as in the preceding discussion, God is all in all.

\section{Without...Parts}

Classical Theology affirms that in himself God is pure, undifferentiated unity and simplicity, or "without...parts," as the "Westminster Confession" put it. In our thinking about God there is complexity, says the classical theory; but no counterpart for this complexity exists in God himself. We think of God as having a plurality of desirable attributes or predicates; and we have many names for God's diverse parts-omniscience, omnipresence, omnipotence, omnicompassion, and so on; but in God's own nature, these multiple attributes are so thoroughly integrated that the many are simply one. We think that God performs many acts, knows many things, is present with many individuals, causes many events, loves and is compassionate toward many creatures; but in God's own reality, all this apparent diversity exists as pure and undifferentiated Parmenidean unity and simplicity of Being. God is the simplest of all beings, Being Itself, though we think of God as the most complex.

By contrast, Process Theology rejects the classical unbridgeable gap between the way we think about God and the way God really is. As the simplest possible being, God could only be that being than whom none poorer in properties can be conceived. Process Theology conceives of God as the supreme, selfconscious, unitary individual who is richest, not poorest, in good-making properties, and who is capable of endless further enrichment through infinite creativity. No other being surpasses God in complexity or any other desirable attribute, but an endlessly creative God is constantly self-surpassing. God's experience of value is enriched continuously through ongoing interactions with created worlds. Instead of being without parts, an infinite number of real parts exist, not just in our thoughts, but in God's own concrete actuality. In the final chapter of this book, we will return to the topic of God's simplicity and complexity.

\section{E. Without...Passions}

The most dramatic difference is that Classical Theology refuses to attribute any feelings to God; whereas Process Theology sees feelings as the very essence of God's love, mercy, and compassion. Most Greek philosophers depreciated the affective, appetitive parts of the human soul; feelings and desires were deemed 
greatly inferior to rationality, thus altogether unworthy of Divinity. Aristotle's Unmoved Mover was "impassible," meaning "without any feelings whatsoever-totally devoid of all affections and desires." His God is emotionally as well as physically unmoved and thinks only about thinking, never about our world and its denizens. Neither omniscient nor omnicompassionate, Aristotle's Unmoved Mover knows and values only logic, thinks without feeling about thinking-nothing else, and does not know or care about us or anything in our world.

Regrettably, the earliest Christian theologians accepted Greek philosophical prejudices against feelings. The lavish emotional, affective, and appetitive language applied to God in Biblical religion was then regularly dismissed as woefully inadequate metaphorical speech; and all spatial and temporal imagery was branded as totally misleading and impious metaphor. In Classical Theology, human beings were made in the rational, not the affective, emotional, or physical image of God, who is literally impassive, empty of all feelings whatsoever, thus not literally loving, merciful, or compassionate.

The God of Classical Theology is not literally or physically male because he has no body at all; yet, psychologically and behaviorally, this God is stereotypically masculine. Like big boys who don't cry, the classical God has absolutely no feelings, emotions, or desires whatsoever about anything. Reflecting a tradition that dates back at least to St. Athanasius, St. Anselm emphatically denied that the Divine part of Jesus suffered on the cross; only his human nature suffered because "The Divine nature is beyond doubt impassible."12 In Classical Theology, God entirely lacks not just undesirable feelings but all feelings whatsoever. St. Themas Aquinas said that God "loves without passion" and that "Mercy is especially to be attributed to God, provided it be considered in its effect, but not as an affection of passion. To sorrow, therefore, over the misery of others does not belong to God."'13

Anselm, Aquinas, and other Classical Theologians held that we experience God as if he has feelings, but in God himself no feelings exist. This appalling compromise came about when Classical Theologians, led by Philo in the first century A.D., combined two fundamentally incompatible ideals of divine perfection-that of the Greek philosophers, and that of Biblical religion. When forced to choose which religious language to take literally and which to construe metaphorically, the Greek philosophers always won. Their outlook was literal truth, so most of the language of the Bible and of ordinary believers was dismissed as impious and misleading metaphor. Nowhere is the conflict between these two incompatible ideals of divine perfection more obvious than in St. Anselm's description of God as compassionate in terms of our experience, but not in His own being and experience.

Truly thou art so in terms of our experience, but thou art not so in terms of thine own. For, when thou beholdest us in our wretchedness, we experi- 
ence the effect of compassiiion, but thou dost not experience the feeling. Therefore, thou art both compassionate, because thou dost save the wretched, and spare those wwho sin against thee; and not compassionate because thou art affected byy no sympathy for wretchedness. ${ }^{14}$

Thus, in Classical Theology, God is literally impassive, only metaphorically and inaccurately compassionate; and CGreek ideals of Divine perfection always trump Biblical values and ideals.

Ministers dare not talk like that to their congregations! They could not get away with it! Ordinary believersi; are led, or misled, to believe that God is in himself all the good things that "we experience him to be. The "Westminster Confession" says that God is "most loving, gracious, merciful, long-suffering...,"Is then takes it all away witth the qualification "without passions." Classical Theologians drive an infinite mwedge between the reality and the appearance of God. God is really not lovin!!g but appears to be, not compassionate but appears to be, not merciful but alppears to be. Divine appearance corresponds in no way with divine reality!

Process Theologians rejectt such duplicity and hold that God is quite literally all of these immensely gmood things. They think that the Greeks were totally wrong in devaluing all fee:lings and affections and in regarding them as greatly inferior to reason if not "completely worthless. Yes, love, mercy, and compassion always involve cogmitive elements; but without their affective components, their intrinsic signifiiicance is lost. Yes, many desires and emotions are bad and unworthy of God; butt, Process Theology insists, many feelings and desires are exceptionally good aund very worthy of Divinity. The good ones belong to God.

Impassivity, total incapacitation for every feeling, is an imperfection, not a perfection. Feelings are stereotywpically feminine not masculine attributes, but having just the right feelings and desires is one of the most majestic features of both human and Divine persons, male or female. God literally suffers with us in our sufferings and rejoices wiiith us in our joys. God literally preserves and cherishes forever the goodness offf our unique lives, activities, experiences, and values. The created goodness of tthe world is ultimately contributed to God, who does not respond to it "without prassion."

The authors of the "Westmiinster Confession" asserted that the chief end of "man" is to "Glorify God and enjoy him forever,"16 but the classical notion of divine impassivity implies thatt nothing in the universe contributes anything whatsoever to God. What then isi; the point of loving and glorifying God, asks Charles Hartshorne, if God's exmperience and happiness are not enriched one tiny bit by our glorification, lovwe, adoration, and devotion? We benefit from religious devotion, we are told; bsut we and our world mean nothing to God. ${ }^{17}$

In Classical Theology, sinc:e there is no passivity or receptivity in God, nothing that happens within the wworld ever affects God. God is pure act, pure 
causation; the world is totally passive, pure effect. God is in no way passive, sensitive, or receptive in relation to the world; in no way is the world active in relation to God. In no conceivable way is God the effect of anything that happens in our spacetime. The "Westminster Confession" affirms,

God hath all life, glory, goodness, blessedness, in and of himself; and is alone in and unto himself all-sufficient, not standing in need of any creatures which he hath made, nor deriving any glory from them, but only manifesting his own glory in, by, unto, and upon them: he is the alone fountain of all being, of whom, through whom, and to whom, are all things.... ${ }^{18}$

Process Theology replaces divine impassivity with the Doctrine of Contributionism, according to which all created value is ultimately contributed to God, who is enriched by it, feels deeply about it, and preserves and cherishes it forever. God's happiness is enhanced by our happiness, and God's sadness is increased by our sadness and woe. All the good we create is ultimately created for God; all the evil we inflict on any sentient creature is also ultimately inflicted on God. God literally rejoices with all who rejoice, and suffers with all who suffer.

\section{F. Immutable...Eternal}

Negatively, "eternity" means "having no beginning or end." The biblical God exists from everlasting to everlasting. When Classical Theologians accommodated biblical everlastingness to Greek ideas of timelessness, they redefined "eternity" positively (without a negation) to mean "all time all at once." In Classical Theology, eternity is the simultaneity in God of the past, present, and future of all creation-a totum simul. For God, everything happens timelessly, all at once. God comprehends all change and mutability in a changeless and immutable way. In no conceivable respect does God change. God is so "perfect" that any change would be for the worse, as Plato and Aristotle, but not the Bible, decreed.

In Process Theology, God has both an immutable Primordial Nature and a changing or developing Consequent Nature. Change with respect to God's necessary existence or desirable ethical attributes like love, compassion, and moral goodness would indeed be for the worse and would make God unworthy of supreme devotion, service, and adoration. But many kinds of change and many feelings are extremely desirable and valuable, despite what the Greek philosophers believed. Not every change is for the worse; not every change alters fundamental goodness. Some types of change are undesirable but others are desirable. God's experiences and choices change as the Divine Individual constantly creates and interacts with living creatures in spacetime; and this type 
of change is not undesirable at all. In fact, it is just what we would expect of a perfect being if our religious ideals and intuitions have not been perverted by Greek philosophers!

Introducing temporality into the concept of God requires a small modification of the classical notion of divine omniscience. Classically, God knows absolutely everything, the past, present, and future of the entire universe, changelessly, immutably, simultaneously, and infallibly. In Process Theology, God infallibly knows the past and present of any actual universe, plus all general tendencies toward the future. But God can not know future free decisions that have not yet been made because they simply are not there to be known.

Both theologies agree that God knows everything that is there to be known. Unlike Classical Theologians, Process Theologians deny that future free decisions already exist somehow to be known before they are made. God may (or may not) know all possible decisions as possibilities, depending on just how detailed a knowledge of possibilities can be; but God learns which free and creative decisions the creatures actually make only when they are made, not timelessly in advance. God cannot know things as actual until they become actual. God knows all things according to their appropriate modes of beingactualities as actualities, and possibilities as possibilities. All of history-natural, human, and Divine-is a partly unpredictable adventure in creativity for both God and God's creatures.

\section{G. Almighty}

Classical Theology followed Plato's suggestion that God could not be changed or affected either by himself or by anything other than himself, and it regarded causal relations between God and the world as completely one-sided. God is almighty or omnipotent, the sole originative causal agent in all of reality, who determines everything. Indeed, in thinking that anything might exist, God thereby creates its existence; so all possibilities are actual if God knows all possibilities. Through programmed or predestined chains of secondary or worldly causation as we experience them, God ultimately causes everything that happens within the universe; but nothing that occurs within the world affects God or brings about effects within God.

Divine omnipotence, understood classically as ultimate and total causality, implies that no freedom or originative causality exists within the universe or even in God, if all Divine decisions follow inevitably from the Divine Nature. Clearly, creatures have no free will and are not co-creators with God.

Christendom accepted predestination with relatively little protest up to the twentieth century, and those who dissented were condemned as Pelagian heretics. Many Christians now realize that Biblical predestination can be interpreted as applying only to classes of individuals (for example, all who come to believe or to love) that were chosen by God from eternity, but not to specific individuals 
elected eternally. Each individual must freely decide whether to become a member of such classes. In our era, free will is popular in the churches, including those that once championed predestination.

Many religious people now acknowledge the obvious-that without free and genuinely creative creatures, God is responsible just as much for all sin and evil as for all righteousness and goodness within the world. Something essential to human dignity would be lacking if we merely act out a pre-existing script and contribute nothing original and personal to the drama of creation. Classical Theologians squirmed and double-talked endlessly but unsuccessfully to avoid these implications.

In Process Theology, God influences all worldly events, including all occasions of human consciousness; but God does not absolutely determine them. God presents us with possibilities for creative self-development and endeavors gently to persuade us to make the right choices; but there is no compelling, no omni-causation. We are co-creators with God. We originate our own free and creative choices for better or for worse. We are responsible, not God, for our choices of good or evil. Hitler and his cronies and collaborators, not God, caused the Holocaust. Process Theologians refuse to "pass the buck." With Harry Truman, they affirm that "The buck stops here!"

In many ways, Process Theology is much more intelligible and attractive than Classical Theology, so we will hereafter construe the question of God's existence in process terms. The Primordial Nature of God is the locus of transcendence, of necessary existence, and of all other desirable general Divine attributes; so we really want to know if we can and do have good reasons for thinking that God's Primordial Nature and the full actuality of God's consciousness are real. The content of God's Consequent Nature is the world, which undoubtedly exists, so its reality is not in question. What we want to know is this: Is the observable world all that there is, or does it have an enduring holy mind of its own? Does a Divine, Holy World-Soul really exist?

\section{Conceiving of God's Existence}

Does God exist? What do we want to know when we ask? Aristotle said that "There are many senses in which a thing may be said to be," or as President Bill Clinton might put it, "It all depends on what the meaning of the word 'is' is." For Aristotle, possibilities do not exist in the same way as actualities; forms do not exist in the same way as matter; substances do not exist in the same way as attributes. Does God exist in the same way that things ordinarily exist?

\section{A. Ordinary Existence}

Theologians usually insist that the being of God is very different from the being of ordinary everyday things. How does Divine existence differ from ordinary 
existence? Ordinarily, we think that something exists if it (1) is entirely located within our familiar public world of spacetime, as opposed to the spacetime of dreams or hallucinations, (2) occupies a finite region of the everyday public world of spacetime, (3) can be publicly detected in spacetime through sensory perception (directly, or with the aid of magnifying instruments), (4) is the effect of perceptible causes located in common spacetime, (5) is the efficient cause of perceptible effects that exist in common spacetime, and (6) the denial of its existence is not logically self-contradictory. This list applies in past, present, and future tenses. To this list, Charles Hartshorne would add that (7) contingent existence is always competitive and excludes other contingent existence.

Degenerate or marginal senses of "exist" also function in ordinary language. Ideas and fictional entities may be said to exist in our minds, thoughts, imaginations, dreams, or in myths or stories, even though they fulfill only the 6th criterion: Denying their existence is not self-contradictory. Santa Claus, elves, fairies, the present King of France, numbers, logical self-contradictions, and Captains James Kirk, Jean Luc Picard, Kathryn Janeway, and Benjamin Sisko exist only in this degenerate "intramental" or "intrafictional" sense. Fictional roles exclude no other actual beings from the domain of existence, even though the actors playing the roles do. If pressed to say whether they "really" exist, our usual answer is appropriately negative. They are too far removed from our paradigms of ordinary existence. Of course, we can always change our minds if and when convinced that some suspect item really fulfills our most essential criteria.

Many entities in the annals of contemporary science-minded cosmology exist only marginally by ordinary standards. Did an initial singularity exist? Obviously not by the first four criteria. It was not located within our spacetime and did not occupy a finite region of it. Because it was infinitely small, it was not perceivable; and its cause (a collapsing antecedent universe?) was not located within our system of spacetime. Perhaps it did not exist by the fifth criterion: if it is only a theoretical fiction or construct, it had no effects within common spacetime; but if it actually initiated our universe, everything observable is its effect. No self-contradiction results from denying its existence; but since it occupied no spacetime, it is difficult to see how it could exclude the existence of anything else.

Do antecedent, co-existent, or parallel universes exist? Not by the first five criteria, so far as we really know: they are not located within our spacetime, do not occupy a finite region of it, cannot be perceived, are not effects of perceptible (to us) causes, and have no perceptible effects as far as we really know. Perhaps they exist in an expanded, marginal, or metaphorical sense: although they are not in ours, they and their components may exist in some system of spacetime or Superspacetime, as may also the Heaven and Hell of traditional theology, or the many worlds of Big Fizz Cosmology. Denying their existence is logically possible (criterion 6), but mere possibilities are not actualities or 
even probabilities. They do not compete for existence with anything else that we really know to exist, but they may compete for locus in Superspacetime with other worlds.

Does our universe as a whole exist? Not by criteria one, two, four, and five, and only partly by three. It is not located within itself, not a mere part of itself, can be perceived only in part, and is not the effect of causes within itself. Naturalists, who contend that the universe as a whole is eternal, uncreated, and uncaused, deny that it exists in sense four. Because it is not the effect of anything, the whole universe did not result from causes within itself, even if all of its parts are effects of perceptible causes in common spacetime. Theists, Oscillationists, and Big Fizz and Big Divide plenitudists deny the application of criterion four to our universe as a whole because its cause is not a perceptible object within our system of spacetime. Can we deny its existence without selfcontradiction? This may be something like denying our own existence without self-contradiction. At any rate, since it includes everything whose existence we could ever verify, it does not compete for existence with anything verifiable.

Did inflation exist? We do not know, but its partisans affirm that it somehow "in principle" existed in senses four, five, and six: its in principle perceptible causes were there in the earliest fractions of a second of our spacetime system; cosmic isotropy and the distribution of galaxies and stars are its perceptible effects; but denying inflation is not self-contradictory. Inflation would compete with a more leisurely pace of cosmic expansion during the fraction of a second that it supposedly existed.

Do the infinitely condensed singularities at the cores of black holes exist? Perhaps, at least in senses one and three through six. These singularities have a position in our spacetime, but since they have no magnitude (like Cartesian minds) they do not occupy a finite region of it. With powerful telescopes we can look toward their black cores, determine that they are caused by gravitational collapse, and see some of the stuff they consume. Their effects are perceptible, even though they are not. We can think consistently about their possible nonexistence; and since they have a definite locus, their existence might exclude the presence of other black holes in that locus.

Did the Big Bang exist? Probably, at least in senses five and six. Its effects surround us and are us; thoughts about its non-existence are logically coherent. It does not seem to satisfy the first, second, third, and fourth criteria. It was not located within our system of spacetime because it is our system of spacetime in its earliest stages; for the same reason, it does not occupy a finite part of familiar spacetime because it encompasses all such regions; its very early stages may have been in principle perceptible but were definitely not so in practice. Its cause was neither perceptible nor natural, but its existence excludes the existence of other universes that might have been created instead.

Do non-extended Euclidean points exist? When conceived of as mere points, ${ }^{19}$ do particles like quarks, photons, electrons, and monopoles exist? 
Some physicists regard this as just a careless way of speaking about "point-like" entities that are very, very small; ${ }^{20}$ others suggest that the notion "has reached its limits of validity and usefulness." ${ }^{\text {21 }}$ By criterion one, if they are anything more than purely conceptual constructs, they have position but no magnitude or volume within real spacetime. By criteria two and three, they clearly do not exist: they are too small to be regional; and they are in principle imperceptible. They do not exist in any obvious way by criteria four and five: if they have perceptible causes or effects, the process by which this happens is very mysterious indeed; only entities with magnitude or spatial extension are perceptible and have perceptible effects. Incidentally, most philosophers today reject Cartesian dualism with its non-extended minds and extended matter mainly because no one can figure out how non-extended entities can act on extended entities; but if real matter is also non-extended, the mind/matter problem is a whole new ball game! So, too, if real minds are extended! By criterion six, non-extended points are not logically necessary beings. In no clear sense could their existence be competitive, unless one point excludes another; but since they are all in some sense identical, counting them might be difficult.

Do non-extended Cartesian minds exist? Here philosophers disagree about the answer but not about the meaning of the question. Dualistic mind/matter interactionists think that non-extended minds exist only in senses four and five: they are affected by bodily events, and they cause and are affected by bodily events. By criterion six, the existence of other minds can be denied without selfcontradiction, but not our own. I contradict myself if I deny that I exist. Descartes was right about one thing; unless I exist I cannot deny that I exist. Materialists affirm that minds exist as brains in public spacetime, and they can be perceived if our skulls are cracked open; but Dualists and Idealists deny that minds exist in senses one through three. Clearly, our direct access to our own conscious awareness is introspective, not sensory. Since minds have their own unique identity, they exclude other minds.

Now for the really important question: Does God exist? Popular religion conceives of God as an old, gray bearded, white skinned, blue eyed, male humanoid, dressed in a white robe, sitting on a throne. So conceived, God would exist in something remotely resembling the first three and the fifth and sixth criteria, except that the relevant spacetime system is that of Heaven, or both Heaven and earth, but not this world alone. If these criteria are strictly applied only to their natural home-the everyday spacetime of this worldnaturalists are correct: God no more exists than fairies, elves, unicorns, and winged horses. Clearly God does not exist in the ordinary way, but then neither do most if not all of the other things or realities just discussed. Does God exist in some extraordinary way? Is God's existence at all intelligible?

Paul Tillich insisted that it is atheistic to say that God exists, meaning in part that thinking that God's being is like the being of ordinary things is totally wrong-headed..$^{22}$ Amazingly, Naturalists, Classical Theists, and Process Theolo- 
gians fully agree that God does not exist-by most ordinary criteria. They agree that God does not fulfill any of the first four criteria. Neither does the universe as a whole, for that matter. God is not a finite physical, perceptible object or being located within a finite region of our system of spacetime. We could never literally see God sitting in a chair, standing by a waterfall, or walking through a garden.

Naturalists insist that God does not exist by any of the seven criteria, and this settles the question. Theologians, both classical and process, think that God fulfills the fifth criterion by being the efficient cause of the Big Bang that created our universe, and perhaps by causing miraculous events within the universe. Process thinkers, who view the universe as the body of God, think that God fulfills criterion 3 in principle, though in practice we cannot perceive the whole universe, the whole Consequent Nature of God. Classical Theologians would not agree because they think that God is completely incorporeal or disembodied, that God occupies no space, includes no space, and has no position in space; for that reason an immaterial God could not be perceived.

Naturalists contend that God's existence is a contingent matter and thus fulfills criterion 6, but many theologians in both camps think not, agreeing with St. Anselm that necessary existence is an essential divine perfection and that it is logically self-contradictory to deny the existence of a perfect Being whose non-existence is not possible. Theologians also insist that nothing could compete with God's existence, and in that sense God's existence is not falsifiable.

Unlike Naturalists, theologians in both camps insist that the question of God's existence or reality is not definitively resolved just because God does not fulfill the first four criteria. The same must be said for singularities, as well as for the universe as a whole, for non-extended Euclidean points, quarks, electrons, and for Cartesian minds. This means only that God's existence is radically different from that of ordinary everyday things and that having a unique mode of being is integral to Divine perfection. Not fulfilling criteria four, six, and seven means that God exists necessarily; and, since every other ordinarily existing thing fulfills criteria four, six, and seven, ordinary existence is contingent existence. We must now give more attention to this distinction between necessary and contingent existence.

The Teleological Argument for God developed in the next chapter reasons from the observed order or design of the world to the existence of an intelligent and benevolent Designer. The Cosmological Argument developed in the final chapter reasons from our experience of the contingent existence of the world to the necessary existence of God. Whether this reasoning is sound must be and will be considered in these later chapters. For now, we must try to comprehend the difference between contingent and necessary existence, as understood in philosophical theology. Much that is theologically significant hangs upon this distinction. 


\section{B. Necessary and Contingent Existence}

Formal (or modal) as well as factual (or ontological) dimensions of meaning belong to both necessary and contingent existence. Both logic and ontology inform us about their differences and similarities.

\section{Necessary Existence}

Formal meaning: Existence that could not not be; non-existence is not possible. Denial of necessary existence in this formal sense is logically selfcontradictory.

Factual meaning: Existence that is self-sufficient, eternal or everlasting, uncreated, and indestructible. Denial of necessary existence in this factual sense is not self-contradictory.

\section{Contingent Existence}

Formal meaning: Existence that might or might not be; non-existence is possible. Possible or actual non-existence.

Factual meaning: Existence that is causally derived from or dependent on something other than itself; if something exists contingently, it has a cause. Contingent existence is created and destructible. Denial of contingent existence in either the above formal or the present factual sense is not self-contradictory, though it may be factually false when contingent entities really do exist.

Usually, contingent existence both comes into being and perishes in time; but it is logically possible for an existing thing, for example, an everlasting universe that does not come into being and perish in time, to be causally dependent on God in some ways throughout endless time. Big Bang Cosmology shows that our world is not like this, however, for it came into being within the finite past.

In Classical Theology, necessary and contingent existence mark the difference between a supernatural God and the natural world. In Process Theology, they mark the difference between the Primordial Nature or general abstract essence of God and the contents (some world or other) of the Consequent Nature. World-events come into being and perish to themselves in time; then they are assimilated into God and never perish in, to, and for God's contingent Consequent Nature. God remembers, preserves, and cherishes created actualities everlastingly. They are ultimately integrated into the contingencies of his Consequent Nature, where they are never lost. (Masculine pronouns are applied to God only as a last resort in Process Theology for simplicity of expression and should not be taken literally.)

Classical Theology treated every general aspect and every particular detail of God's reality as necessary; yet it insisted, inconsistently, upon the contin- 
gency of creation itself and of God's will or choice to create. Process Theology assigns necessity only to the abstract essence or Primordial Nature of God that persists unchanged through all other changes. The Primordial Nature includes not only God's envisionment of possibilities for creation, but also God's necessary existence, necessary creativeness, and necessary and flawless capacities to know, love, influence, and be influenced by all creation. God's Necessary Primordial Nature cannot possibly not exist; and it is self-sufficient, everlasting, uncreated, and indestructible. The Primordial and Consequent Natures are logically or conceptually distinct, but they are never separated ontologically. They are not two different Gods, but are inseparable ontological aspects of the full reality of one God who exists necessarily but creates and interacts contingently with particulars.

\section{Critique of Process Theology}

On many issues, Process Theologians disagree among themselves and not just with atheists and Classical Theologians. To fully understand and appreciate disagreement within the process camp, read Lewis Ford's Transforming Process Theism, where Ford even disagrees with himself $!^{23}$ Almost all Process Theologians agree that Whitehead's original formulation of Process Theology requires many additions and revisions. Many objections to this novel temporalistic way of thinking about God are raised by those who have no stomach for theology at all. These will be faced in the following chapters. Other objections are raised by those who are greatly attracted to many features of process thought but who believe that a few amendments are needed to bring it in line with certain religious and rational requirements. We will next look at a few ways in which I and other sympathetic critics think that Process Theology needs to be amended.

\section{A. God's Influencing and Being Influenced by the World}

Mainstream Process Theology has serious problems about God's ability to know, value, and retain the values inherent in the subjective immediacy of moments of created time, and about God's ability to influence individuals within the world. Its fine-grained analysis of "time," taken from Whitehead, seems to be incompatible with its religiously appealing claims that all created values are ultimately contributed to God and that God's responsiveness to individuals and occurrences within the world adds value and direction to them.

Except for the data and subjective aims that nascent occasions receive initially from their predecessors, the free and self-creative moments of subjective immediacy that make up our ongoing streams of consciousness are understood by most process thinkers to be closed to all other happenings. They can neither influence nor be influenced by, neither experience nor be experienced by, other entities during their own brief "duration" or "specious present" of 
self-creative independence. Supposedly, this causal shut-up-ness prevents the independence, freedom, and self-creativity of temporal occasions from being overwhelmed by the presence and power of God or by past events within the world. Once they get underway, temporal occasions are closed even to God, Whitehead thought, Most process thinkers agree. This implies that God can know and value temporal occasions only after they achieve their final "satisfaction" or unified definiteness, but not in or during their self-creative subjective immediacy. About that, God can know nothing whatsoever. Except at the very beginning and end of their becoming, God can neither experience and influence nor be experienced and influenced by created actual occasions.

For preserving creaturely freedom, the standard process fine-grained analysis of temporality may be overkill. From a deep religious perspective (about which there is ample room for honest disagreement), the God of Process Theology may be deficient or less than perfect because he cannot be omnipresent to, omniloving of, or omniscient with respect to all actualities, specifically, those that are still becoming. That they can be present to God is also doubtful because God is also still becoming. At best, the standard process God can be present with, love, and know our subjective immediacy only as it was, perhaps as we would know it through very short term memory, but never as it is in its vibrant subjective immediacy of becoming where its primary value resides.

Robert C. Neville, whose own concept of God is very weak, argued effectively that the most important values of existence are located in the immediacy of subjectivity and that the God of mainstream process thought is gravely defective in being unable to know, love, and evaluate the immediate subjectivity of entities in becoming. In being unable to know immediate subjectivity directly, God also cannot remember it and thus cannot give it objective immortality. ${ }^{24}$ The chief culprit here is the prevailing process analysis of the fine-grained features of temporal becoming, which for many reasons needs to be modified or abandoned, as explained later. Process thought's greatest contribution to theology is its emphasis on God's temporality and on God's sensitive and receptive responsiveness to events in the world, but not its fine-grained analysis of the nature of time itself as it applies to God and to us.

Contributionism, the view that all created values are ultimately contributed to God, requires a deeper understanding of divine time and causation. The selfcreative independence of creaturely events would still be intact if God's own temporally ordered subjectivity is reconceived to be continuously but passively present to, sensitive to, and receptive and appreciative of, developing occasions within the world in their immediacy of becoming. As Neville suggests, God might even be able actively to influence the internal concrescence of created events, ${ }^{25}$ but this would have to be through very modest spiritual promptings that do not overwhelm our freedom. 
Traditional Whiteheadian thought distinguishes two kinds of time or process, the transitional succession of two or more atomized actual occasions, and their singular internal self-development or concrescence. Human consciousness and all other enduring realities within the world are composed of prolonged societies of successive momentary occasions. Charles Hartshorne modeled God after this pattern; God is an infinitely prolonged society of divine actual occasions. Whitehead, by contrast, thought that God is a single, continuous, everlasting concrescence; and many process thinkers side with Whitehead on this issue, as do I. My view is that all of time, God's and ours, is much more like concrescence (properly reconceived) than like atomized actual occasions. Concrescence occurs continuously; atomization occurs discretely. Discrete actual occasions supposedly reach a stage of final unified definiteness or "satisfaction" when their internal processing is completed. This achieved definiteness is then hurled at or infused into succeeding occasions as "data" to be assimilated, then further processed by them in light of their own emerging objectives, aims, feelings, and choices.

Most process thinkers accept the theory of discrete or atomized actual occasions within the world, even if not for God; but I, for one, just cannot find any totally discrete atoms of time anywhere; and I am convinced that the conventional process account of the very nature of time must be challenged. We experience becoming, I believe, as continuously (that is, without sharp atomization) exhibiting degrees of unified definiteness, receiving and transmitting data, manifesting ongoing and usually extended-range purposiveness, exercising selection periodically, interweaving and refining feelings, being receptive to novelty and open possibilities, and perishing at some indefinite point. Past moments flow into present moments more like streams than like squirts. Yes, there is perpetual perishing; but past moments penetrate into present moments, and present moments penetrate into future moments, without abrupt atomization. At a very fine-grained level (tenths of a second or less), our conceptual distinctions between past and present, and present and future, are arbitrary. At no absolutely precise experiential point does the past lapse into the present, which then in turn becomes abruptly past to its successor. Receptivity, definiteness, continuity, duration, purposiveness, synthesis, unification, achievement, self-enjoyment, and self-creativity are ongoing features of temporal becoming, the stuff we and God are made of; but time is nowhere sharply atomized into discrete epochs that endure only for a jiffy.

Except for never forgetting the past, God's experience of becoming is not radically different from ours, I believe, with respect to continuous concrescence, persisting creativity, ongoing receptivity and synthesis, constant unity and definiteness, and enduring responsiveness. God constantly assimilates data and value from the world's past and present (God's Consequent Nature) and gives relevant novelty, purpose, and direction back to developing events within the world (God's Superjective Nature). We lose much of the past because our 
capacity for memory is very imperfect; but God's memory, by contrast, is flawless. God assimilates the achieved value of the world without losing the value of its subjective immediacy because God directly experiences our subjective immediacy-something else that orthodox process thought cannot affirm. Our subjective immediacy perishes to us but not to God, who knows it forever as directly as we do fleetingly, and who cherishes it everlastingly. ${ }^{26}$ Things become settled and definite for God as they do for us, not abruptly but continuously. At some indefinite point, experiences become definite and past for God, as they do for us. Neither God's nor our own temporality is sharply atomized into completely discrete occasions. God continuously experiences and grows in value-satisfaction in being acted upon by and in acting upon the world; but neither God nor we experience the terminal technical "satisfaction" of the abrupt termination of temporal occasions accepted by most process thinkers. Time just isn't that atomized or abrupt.

As Lewis Ford heavily emphasizes, ${ }^{27}$ Whitehead's position, widely held, was that God is a single, present, everlasting, active experience (or concrescence, to use the technical word for it) that never reaches final completion, unification, and definiteness (or technically, "satisfaction"). This implies that God's consequent nature cannot influence particulars in the world in any way, for only entities that have achieved final definiteness can exert efficient causal influence on ("objectify" themselves within) other entities. God cannot be prehended or experienced. Ford's latest position, proclaimed in his Transforming Process Theism, retains God's influencing the world primarily if not entirely by persuasion, but Ford drops divine influencing through efficient causation from past definiteness into present becoming. Ford's God, like Whitehead's, never achieves "satisfaction" and thus can never be prehended or experienced by us or anything else. Religiously, this is a fatal flaw.

Ford recognizes that the traditional process account of temporal concrescence must be revised; and he proposes that "concrescence" be extended to cover the future. In some mysterious way, God exists in, concresces in, acts in, and dispenses creativity from the future. God provides initial aims and creativity to worldly events through some spooky form of causation from the future.

I am convinced that process philosophy's unresolved problems can be best remedied by drastically revising the very notion of temporal concrescence, not in Ford's way, but much more radically than he proposes. Process thinkers, I believe, must go back to square one, reinterpret the very nature of time itself, and give it a radically non-Whiteheadian analysis. The outcome must not deny that process is metaphysically fundamental, and it should save all that can be saved of Whitehead and Hartshorne. Here are some preliminary and admittedly incomplete suggestions about how to do it.

Time is clearly the stuff that reality is made of, but what is time made of? Following Whitehead, most process thinkers identify two distinct types of temporality: (1) transition, the succession of atomized temporal occasions after 
the self-creative becoming of each one ends, its subjective immediacy ceases, it achieves the unity, definiteness, and permanence of being called "satisfaction," and it objectifies what it can of itself for its successor(s) as it perishes; and (2) concrescence, the internal process of becoming of each single atomized occasion, its subjective immediacy, self-creativity, and self-enjoyment in the present moment. Once initiated, the becoming of an immediately present occasion cannot be influenced or experienced by anything outside itself, said Whitehead. Becoming, this second mode of temporality, also involves temporal elements-both duration or temporal thickness and succession. Human level occasions or concrescences endure from a twentieth to a tenth of a second; gluon concrescences that hold quarks together endure for only a trillion trillionth of a second; ${ }^{28}$ but no occasions are infinitesimally thin.

The elements of concrescence that endure briefly but successively together in their internal becoming are so organically interrelated that they cannot be separated or sub-divided into distinct atomized units like those involved in transition. They are not separate occasions, only components of a single occasion. These inseparable elements, most of which are classified as successive "phases" of becoming or concrescence, can be differentiated conceptually; but they cannot be sub-divided physically or metaphysically.

The successive phases were analyzed "genetically" by Whitehead in slightly different ways in different writings, ${ }^{29}$ but they involve at least (a) an initial phase in which a nascent occasion both derives data from (prehends) its predecessor(s) and derives its initial aim from God. The received initial aim consists of an awareness of the possibilities or "eternal objects," some quite novel, that it might actualize, as well as a slightly weighted aim, purposiveness, or lure towards the best of these possibilities; (b) an intermediate phase of selfcreativity in which it decides for itself what it will be, what real or immediately relevant possibilities it will actualize, best or not; and (c) a final phase, called the "satisfaction," in which its definiteness and unity are finalized, after which it perishes and infuses what it can of itself into its successors; (d) the whole becoming of concrescence is characterized by a "subjective form," which is how the occasion feels, processes, integrates, and values its constitutive elements and by (e) creativity, the presumably ubiquitous category by which every occasion is partly self-creative.

The subjective form persisting throughout each occasion provides it with a kind of unity from the outset to the end, but how an occasion reacts to its components gradually develops, grows, and becomes more unified and definite. Subjective forms are thus odd mixtures of unity in variety, of beauty as classically understood. Note carefully that all the elements that define present becoming are modeled on psychology-experiencing data (receiving information), having aims, purposes, attractions, revulsions, feelings, and values, awareness of indefiniteness, alternatives, and choosing among them, as well as discerned duration, unity, and definiteness. In most occasions, Whitehead thought, these 
psychological constituents of time itself merely exist unconsciously; only rarely do they rise to consciousness.

This Whiteheadian model of temporality is wrought with perplexities. For one thing, although the elements composing becoming are drawn from psychological self-awareness, the theory, which pays lip service to faithfulness to experience, does not order these elements accordingly. In lived experience all these elements are like subjective forms-they occur throughout becoming, not sequentially. They pervade our present moments of becoming; they do not follow one another successively in experience.

Another serious difficulty springs from Whitehead's insistence that only at its outset can an actual occasion experience anything outside itself, and only after it perishes can anything outside itself, and including itself, experience it. Only after it achieves the fully unified definiteness of terminal "satisfaction" can anything outside of itself prehend it. Applied to God, a serious theological quandary results. If God is a single everlasting concrescence with no beginning and no end (no satisfaction), it follows logically that God never experiences anything, and nothing else ever experiences God. God never has either an aboriginal beginning or temporal beginnings where data can be received; God also never has endings or "satisfactions" where he can objectify himself for others. Thus, God cannot know us and we cannot know God! What an embarrassment for a theology that revels in God's availability to us and our availability to God! Something has to give.

The Hartshorne/Cobb view that God is an infinitely prolonged society of actual occasions rather than a single everlasting concrescence is initially attractive because from this perspective God has temporal beginnings and endings (satisfactions); thus God can receive data from creation and provide feedback to it. Before you embrace this view, please consider just one of many difficulties with the society of occasions theology. How many divine occasions must occur per second for God to be present at the outset and terminus of a succession of gluon occasions, each of which endures for a trillion trillionth of a second or less? Like most other enduring entities composed of societies of successive occasions, gluon occasions do not all occur in sync; they are not like those rare fireflies that flash simultaneously in perfect harmony. So how densely packed would God's occasions have to be just to cope with all the out-of-sync gluons in existence? How densely packed per second must God's occasions be just to cope with gluons? Now consider all other kinds, durations, and unsynchronized varieties of occasions composing our incredibly complex universe. How dense must a Divine society of actual occasions be in order to be there at the beginning and end of each occasion in the world? The obvious answer is that God's occasions would have to be infinitely dense! God always has to be there doing his job; God can't just flash in and out of existence; God must exist continuously; God has to be an infinitely dense continuum just to cope; God has to be an everlasting concrescence continuously interacting with all creation. God must 
be an infinitely prolonged, infinitely dense continuum; no matter where we cut, God is there. But if God is an everlasting continuous concrescence who acts upon and is acted upon by the world, the very notion of concrescence must be drastically revised.

Applied to ourselves, the requirement that only terminal satisfactions can be experienced means that, despite the vaunted value of subjective immediacy, we can never experience or know ourselves directly and immediately. That is, the occasions that constitute our stream of consciousness cannot know themselves directly and immediately. Process thinkers generally accept Hartshorne's view that all introspection is really retrospection on immediately past selfoccasions. This means that we never really know or experience ourselves in the full subjective enjoyment and self-creation of the present moment. We know how we were, but never how we are. Self-enjoyment and self-creativity are gone by the time they are experienced, so these vital values are never really known as such. This is another very good reason for revising the process analysis of the becoming of the present moment. How can anything be remembered (retrospected) if it was never experienced or known in the first place?

"Satisfaction" is the most vicious culprit in the standard process analysis of temporal concrescence. As it terminates, every occasion supposedly resolves all its indefiniteness and achieves absolute unity and definiteness. This presumably happens every fraction of a second in human experience, but this is totally at odds both with quantum physics and with our own immediate experiences of temporal becoming.

Quantum physics says that real indefiniteness is a persisting feature of quantum-level physical occurrences, and quantum non-locality involves immediate perceiving and knowing, not temporally ordered retrospection. Indefiniteness of position or locus and velocity are only occasionally and never simultaneously resolved. Wavicles, which cannot be rigidly atomized, may persist through extended periods of time as unresolved sets or superpositions of pure potentialities until their wave functions collapse, according to some quantum physicists. Instead of classical definiteness of "simple location," wavicles are smeared out over small but indefinite regions of the spatiotemporal continuum. Particles are embedded in waves, and waves are embedded in even broader quantum fields. But none of this could be true if every occurrence begins in disarray and ends in completely unified definiteness. Certainly, our own temporally ordered subjective experiences of becoming do not begin or end that way.

If all indefiniteness is totally resolved every tenth or so of a second in terminal satisfactions, none could ever be transmitted from one occasion to the next, so no indefiniteness should ever persist in our lives. In reality, our temporal streams of awareness are riddled with all kinds and degrees of enduring disunity and indefiniteness, mixed with persisting unity and definiteness. If Whitehead's theory of becoming-terminating-in-satisfaction were true, we should never experience any lingering perceptual, conceptual, volitional, moti- 
vational, or affective confusion, unclarity, ambivalence, ambiguity, or indecisiveness whatsoever. But we do! So Whitehead's theory of becoming/concrescence is wrong. To account for the transmission of indefiniteness, we could say that our "satisfactions" end in definite indefiniteness, but Whitehead's account of concrescence cannot be saved by that kind of double talk.

Traditional Whiteheadian models or metaphors for temporality were drawn from two primary sources, our own subjective experience of temporal selfhood and quantum physics. These are the right models, but I doubt that Whiteheadian analysis does real justice to either. My recommendations for reform, especially for rethinking the whole notion of concrescence, will doubtless require refinement, but here is a beginning. (1) The elements of concrescence identified by Whitehead do not follow one another progressively and successively; they are present continuously through every occasion. (2) Occasions within our own streams of consciousness are not analyzable correctly into discrete atoms or epochs of experience; they begin and end indefinitely. (3) The epochal or atomistic model of time that Whitehead abstracted from quantum physics as he knew it is an incomplete and misleading model; he neglected waves and quantum indefiniteness; and non-local immediacy was unknown to him.

(1) In my (our) own immediate experiences of present moments, admittedly durational, the elements that Whitehead adduced to be successive do not occur successively but continuously. They are simultaneously present throughout concrescence, just like subjective forms. Moments of subjective immediacy are continuously and constantly being flooded with data or derived information; these data, feelings about them, valuations of them, and aims with respect to them are continuously present throughout every present moment of self-becoming, along with high degrees of unity and definiteness. These elements don't just occur only at the beginning, in the middle, or at the end respectively of present moments. Temporalistic consciousness continuously synthesizes data, possibilities (thoughts), and feelings into high degrees of unity and definiteness.

Furthermore, practically all of this happens almost unconsciously, automatically, and irresistibly; and very little of it can be accurately described as involving conscious choices or voluntary effortfulness. Creative synthesis does not involve intentional creativity. We cannot choose to turn on or off our continuous synthesizing of multiplicity into unity. We cannot control it; it transpires not because of us; it happens to us and maybe even in spite of us. Decisions, properly so described, occur only intermittently, not in every present moment, certainly not every tenth of a second or so. Active synthesis of plurality into unity is always there in consciousness, but not active choosing or voluntary effortfulness. Freedom is intermittent, not ubiquitous. Arriving at a real decision about anything takes a while, and the preliminaries run through many present moments during which deliberations but not decisions occur. At times we actively deliberate, but even that takes a lot of time, not just fractions of a second. Our subjective aims, our plans of life, cover extended periods of time, 
not just the present moment. They do not achieve determinate "satisfaction" every tenth of a second. They exist continuously, not discretely.

High degrees of definiteness and unity run throughout our present moments of subjective immediacy, self-enjoyment, and self-awareness. Decisions, occurring only intermittently but not constantly, do cut things off into memorable definiteness; but unity and definiteness are constantly there to a significant degree, and I am always "satisfied" in that technical sense of the term. Clearly, unity and definiteness do not happen just at the "end" of each present moment. Time is not experienced as a series of oscillations that begin with indefiniteness and end with definiteness. Experienced temporality melds indefiniteness with definiteness throughout; it does not vacillate identifiably between indeterminate beginnings and determinate endings. Present moments don't even have discrete and clearly identifiable beginnings or endings. That brings us to atomization.

(2) Process thinkers should just drop the claims that the elements of concrescence exist successively rather than together, and that temporality, whether divine or in the world, is sharply atomized into discrete occasions. This conceptual theoretical construct, out of touch with all experience, creates all the problems. Our experiences of subjectivity are definitely not so synchronized or atomized. A quantum-like indefiniteness characterizes every present moment of temporal concrescence, experientially. Over the very short term, past, present, and future are not sharply divided or atomized. Instead, they interpenetrate and flow continuously, not abruptly and discretely, into one another. Experientially, we cannot tell with infinitesimal precision where the present ends, the past begins, or the future arrives. Perhaps something like this is what Lewis Ford means by the presence and activity of the future; but over the very short run it makes just as much sense to speak of the presence and activity of the past.

Our philosophical theories, including our theories of time, should be grounded in both subjective and scientific experience. Real time, the basic stuff of reality itself, has to resemble experienced time, which is more like a continuum than like atomized squirts, bursts, flashes, pulsations, or epochs. This does not mean that it is infinitely divisible into real parts capable of existing independently of durations; but the boundaries of its real parts, concrescences, are quantum-fuzzy; their durations flow into one another and are not sharply differentiated. Over fractions of a second, indefiniteness separates immediate past, present, and future. This does not mean that experiences and events are not at some point definitively past, over and done with; but we can't tell precisely when because no absolutely precise "when" separates the present from the past or from the future. Rejecting temporal atomism does not mean that no intrinsic causal connectedness exists between events; rather, it makes this intelligible. The energy of one event infuses and flows imperceptibly and directly into the energy of another, and we can tell exactly where one (the temporal cause) ends and another (the temporal effect) begins. The cause is, in part, in the effect. 
Few process thinkers have questioned Whitehead's sharp temporalistic atomism; but his analysis of becoming or internal concrescence confuses our theoretical constructs, Whitehead's constructs, with both temporally ordered experience and reality and thus commits Whitehead's own "fallacy of misplaced concreteness." Theory should coincide with experience. When Hartshorne confronted the substantial discrepancy between our experience of time and the mainstream process theory of time, he conceded, in these words, far too much.

We here confront one of the subtlest problems which event pluralism has to face, that of the apparent continuity of process, its apparent lack of discrete units. Dewey, Bergson, Peirce, all three careful thinkers much interested in the analysis of experience as such (and to them Husserl and Heidegger could, so far as I know, be added), found no definite discreteness in the becoming of human experience. And no process directly exhibited in human experience seems to come in clearly discrete units. Here is a splendid example of a seemingly strong (empirical) case for a philosophical view, a case which is nevertheless inconclusive, and indeed can be opposed by perhaps a still stronger though non-empirical case. ${ }^{30}$

That the Whiteheadian theory of the very essence of time is radically nonempirical is a devastating admission! The theory fails to agree both with selfawareness or subjective immediacy and with physics, quantum or otherwise.

(3) Whitehead's epochal, atomistic theory of time was at best only incompletely abstracted from quantum physics as he knew it in the 1920s, and, as suggested already, it is definitely at odds with quantum physics as we know it today. Its physical as well as its psychological models for temporal atomization are inadequate and misleading. Contemporary readers familiar with quantum physics understand that it blends indefiniteness with definiteness, particles with waves. The standard Whiteheadian view of time was modeled microscopically on particles alone, not on wavicles. Macroscopically, it was based on successive and discrete bursts and flashes, while ignoring their underlying wavelike constitutions and origins. Actual occasions are atoms or particles, not of space, but of time; each is discrete; and each has a definite beginning, middle, and end. So the theory says, but the theory is wrong.

What would happen if our theory of time gives at least equal weight to the wave model of differentiation? Definiteness (atomization or particularization of sorts) would still be there, but it would be smeared out, have fuzzy edges, and lack simple temporal or spatial location and infinitesimally precise discreteness. Waves have definite peaks and troughs, but they flow almost seamlessly into one another. Like circles, determining exactly where one ends and another begins is quite arbitrary. So it is with actual occasions. We cannot leap from "All energy is transferred only in discrete packets or quanta" to the conclusion that "All energy exists only in discrete particles or quanta," for some energy 
exists as indiscrete waves and encompassing but indefinitely bounded fields, not as discrete particles; and time is like that. We should go back to discussing "events," as in Whitehead's pre-systematic metaphysics, rather than "actual occasions," technically conceived.

Since no concrescences, not just God's, but ours as well, have absolutely discrete beginnings and endings, they cannot be the absolutely closed units that Whitehead took them to be; and the absolutely definite beginnings and endings he required are not the insuperable obstacles to mutual and self experiencing that he took them to be. Past events can penetrate present events sufficiently for efficient causation. Inherited definiteness of data, energy, purposes, and feelings are always and continuously mixed with degrees of openness and indefiniteness. No strictures pertaining to terminal "satisfactions" preclude one event's direct awareness of its own or another's concrescent subjective immediacy because significant degrees of unity and definiteness are always present, and because counting concrescences as "first" then "second" is arbitrary over the very short run. Because something like instantaneous non-locality obtains within events, they can know themselves directly, not merely retrospectively.

All of this should be just as true of divine as of human level concrescences. God's ongoing concrescence never begins or ends absolutely; yet, incredibly significant degrees of unity and definiteness are always present to God. This includes the complete definiteness, the full burden, the total joy and worth of the world that God takes into himself and saves forever without losing the subjective immediacy that we creatures lose to ourselves in the perpetual perishing of time. It is not true that God never experiences anything, and nothing else ever experiences God because God is a single everlasting concrescence with no beginning, no end, and thus no satisfaction. If unity and definiteness define "satisfaction," then God's concrescence is always satisfied, continuously satisfied, to a very high degree in this technical sense; otherwise, if achieved only in terminal satisfactions, God's everlasting concrescence has no unity or definiteness at all. God and nothingness would be indistinguishable!

Nothing, especially God, has the absolute beginnings and endings required by the epochal theory of time. All concrescences, including God's, are highly definite and unified throughout. All concrescences, including God's, can receive information without having absolute beginnings; they can transmit data without having absolute endings. Nothing has to await absolutely terminal satisfactions to experience itself or something else, or to be experienced by something else. God and the world are indeed available and open to one another-continuously.

Most process thinkers probably agree with Whitehead that the closedness of concrescences to one another is essential for freedom and self-creation; but this cannot be true if the traditional account of concrescence is flawed from the very outset. (1) Temporal atomism and (2) sequential phases of concrescence just don't exist! For many reasons, our freedom is not overwhelmed by God's presence with and to us in the present moment, contrary to orthodox White- 
headianism. God can be sensitively, passively, receptively present as well as actively present; our capacities for including, recognizing, and assimilating God are exceptionally limited even when God is fully available. God values our conscious individuality with its independence and freedom sufficiently to insure that his immediate presence with and to us does not overwhelm us.

Repudiating temporalistic atomism allows God to know and experience us, not just as we were, not merely after our robust present moments perish, but as we are in the full vibrancy and value of our unique subjective immediacy, selfenjoyment, and self-creativity. This is where our intrinsic value primary resides. To that, God gives objective immortality. Ultimately, we contribute what we are immediately, not must what we were retrospectively, to God. Unhindered by the strictures of technical "satisfactions," which don't exist anyway, God can respond lovingly, providentially, and temporally or historically to particular events within the world as they occur, not in a timeless eternity, not from a nonexistent future, and without having to wait around forever for a Whiteheadian "satisfaction." By reconceiving the present moment of time, all of the religious advantages of process thought can be preserved and can flourish unfettered by untenable and unempirical theoretical distinctions and strictures.

\section{B. Our Freedom and God's Self-Limitation}

God is not the sole creative agent operating in the universe; we creatures are free to choose between good and evil. This is an important part of the process resolution of the problem of theodicy-reconciling the reality of a good and powerful God with the brute fact of evil in the world. This theodicy is developed much more fully in the next chapter, but a difficulty that arises in connection with it must be considered here.

If God is not the sole creative agent in the universe, is this because God freely chose to limit his freedom? Or is it because God is impotent to create unfree creatures or to interfere with creaturely freedom? Process thinkers agree that existing realities are partly self-creative, but they may disagree about whether this is so by metaphysical necessity or by divine choice. Mainstream Process Theologians seem to believe that God is merely the final but never the efficient cause of events within the world; but these terms need to be defined carefully. Some might disagree verbally because they define "efficient" and "final" causation differently. As here understood, Divine efficient causation is God's power to create, infuse, or reorder energy. Divine final causation is God's purposiveness, which includes God's power to present developing spatiotemporal occasions with "initial aims," the set of viable possibilities open to them for both limited and long-term self-creation and choice. (But there is nothing "initial" about them!) Mainstream Process Theologians hold that God influences individuals within the world primarily if not entirely by gently persuading or luring them toward the best, by presenting them with aims that are slightly but 
not overwhelmingly weighted toward the good, but never by directly causing or forcing them to conform to the Divine will. Since miracles, by definition, involve Divine efficient causation, and since God never exercises efficient causation, no miracles or acts of God could inject energy directly into the world or redirect it, either at the beginning or subsequently. God never causes or prevents evil because God totally lacks the power to do so. Since God never causes anything, God never causes evil, if that is much consolation!

Although he would not formulate his position in terms of efficient versus final causation as just defined, David Griffin, among others, vigorously defends this dominant process solution to the problem of theodicy. ${ }^{31}$ Griffin identifies efficient causation with transition between occasions and final causation with the internal concrescence of occasions, (which unfortunately precludes purposiveness or final causation between occasions); but he also recognizes that final causation involves efficient causation. ${ }^{32}$ Mainstream process thinkers hold that God simply lacks the power to bring anything about unilaterally, whether good or evil. This implies, fortunately, that we cannot blame God for evil; it also means, unfortunately, that God could never create a universe out of nothing, or work any miracles, or do anything except nag! God works persuasively, at best, but not efficiently, in all natural causation; but since God never reaches "satisfaction," (on non-Hartshornean interpretations), it is difficult to see how God could even work persuasively.

As exemplified in David Griffin's books on theodicy and in various writings by John B. Cobb, Jr., Lewis Ford, Bowman Clarke, and many others, process orthodoxy says that God's power over the world is primarily if not entirely that of final causation, not efficient causation as just defined. They might word the issue differently, but these thinkers clearly hold that God lacks the power to do much of anything except persuade. God influences the world and its denizens by presenting attractive ideals, by "luring" toward the best; but beyond that God seems to $d o$ very little, if anything.

Process Theologians say that God shares creativity with the creatures, ${ }^{33}$ but this is usually tempered if not contradicted by their insistence that God has no choice in the matter because creativity is a universal metaphysical category that necessarily characterizes all actual entities in all possible worlds. ${ }^{34}$ This implies, says process orthodoxy, that God absolutely lacks the power to create the deterministic universes in which predestinationists, Newtonians, mechanistic materialists, and others believed. God has no choice but to create co-creative creatures; God simply does not have the power to do otherwise, to create absolutely predetermined events, individuals, or worlds.

I would like to see the options open to Process Theology expanded in many ways. To illustrate, let me flesh out briefly a notion of a supremely worshipful being, a being than whom none better or more worshipful can be conceived, that is much closer in some respects to the non-process tradition. It seems to me, and I recognize enormous room for honest disagreement about 
this, that God would be religiously deficient if he really lacks the power to influence or modify events except through persuasion or final causation, and if he absolutely could not create deterministic universes, however repulsive they might be morally and aesthetically, because he lacks the power to do so and not because they are repulsive.

I regard freedom/creativity as highly desirable, but not as a metaphysically necessary feature of the kind of universe that a truly worshipful Divine being would create. This implies, contra Whitehead and Hartshorne, that creativity/freedom is not a metaphysical category that is universally and necessary present in all possible temporal occasions and universes. Universality and necessity can be separated; creativity could be cosmologically universal in our world but not metaphysically necessary for all possible or conceivable universes. Even if creativity exists contingently in all actual universes, assuming more than one, this is by God's choice, not because of metaphysical necessity. If creativity is ubiquitous in our universe, this is because God freely and voluntarily made it so. Ideally, divine omnipotence involves having the power to create both deterministic and non-deterministic universes, but choosing from goodness rather than from metaphysical necessity to create free creatures.

Creativity may not be ubiquitous even within our own universe. It may characterize mainly higher or more complex actual occasions like those in living beings, particularly conscious animals and human beings. Lewis Ford allows that although persisting elemental physical particles like quarks, protons, atoms, and molecules are novel in their individual actuality, they do not exhibit novelty of form. Except for somewhat rare sensitive and creative occasions in the material world, most persisting physical particles just do not have conceptual aims, and do not creatively modify their aims. ${ }^{35}$

But this means that most elemental physical particles manifest no creativity whatsoever. This may also be true of many of the dull moments of human experience. I suspect that quantum-level wavicles are uncreative most of the time, but periodically they may manifest it. As indicated in Chapter Six, neither we nor an ace predictor like God can tell or predict when individual particles will change orbits, exactly where they will appear next within broad-band orbital shells, which slits they will go through, the directions they will fly when scattered, or which ones will decay and produce atomic radiation. Quantum uncertainty, indeterminateness, and spontaneity widely pervade physical reality; but this does not imply their universal presence. Creativity may be neither metaphysically necessary nor cosmologically universal. Either way, when present it is a precious gift of Divine grace.

As usually conceived by process thinkers, God lacks a kind of power that Kierkegaard and so many others believed to be of immense worth-the power to share power freely and voluntarily rather than necessarily. Wouldn't a being than whom none better can be conceived have that kind of power? Wouldn't a truly worshipful God have efficient as well as final causation at his disposal? 
Shouldn't God be able to do as well as lure? Shouldn't God have the power to create life-supporting universes from nothing, or to work an occasional miracle or two? Ultimately, each of us must answer these questions for ourselves; but many devout and thoughtful people answer affirmatively.

Miracles are another can of worms, I know; and the view I will now express is process heresy. But the "omnipotence as only persuasion" God of process orthodoxy seems to me to resemble too much a celestial George Bush, or some other conspicuous wimp, who espouses noble ideals like kindness and gentleness but never budgets for them or does anything about them except cajole and nag. George Bush was not that President than whom none greater can be conceived, and the God of process orthodoxy is not that Ultimate Reality than whom none greater can be conceived! (This was originally written about "Big Bush," as Rev. Jesse Jackson calls him; but it will probably also apply to "Little Bush." Only time will tell.)

Many traditional theologians and believers think that God has the power to create both free and unfree creatures but actually does the second (predestinationists); others think that he has that power but actually does the first (freewillists); others try incoherently to have it both ways. Process orthodoxy says that God just doesn't have it, partly because of a power deficit, and partly because all creatures are necessarily free (ubiquitous creativity).

Without wanting to have it both ways, I and many others think that God has all consistently conceivable power at his disposal, but God uses it freely and benevolently to create free creatures and the kind of universe required to sustain them. Adopting this view would help immensely in healing the alienation between Process Theologians and more traditional believers; but standard brand process thinkers won't like the suggestion.

The alternative process view of God's power, espoused here, concurs with many critics that the divine power-deficit at the heart of the dominant process outlook is religiously intolerable. Only a God who is not a supercelestial wimp is supremely worthy of human worship, service, and devotion, according to this minority perspective. On this voluntary self-limitation view, God voluntarily limits his own power and chooses to share power/creativity with free creatures. God exercises a desirable balance of both persuasion and efficient causation in relation to events within the world. Values, not metaphysical necessities, determine the balance. God is good, not impotent. Events within the world are partly self-creative because God, who could have created another kind of universe, chose instead from the outset to share creativity with us creatures and thus to limit his own power over and knowledge of the future.

Although God's omnipotence was often equated with omnicausality by Classical Theologians, it can mean instead that although God could predestine all, God actually chooses to influence all without determining all. God voluntarily uses his power to do the best that an omni-influential agent could do, which may include creating universes from scratch and performing infrequent 
miracles, as well as delegating creative power to others. Freedom within creation is a deliberate, gracious, and voluntary gift of divine self-limitation, not an impersonal metaphysical necessity about which God has no choice. Process thinkers can hold the minority view that creativity is general if not universal in our cosmic epoch, perhaps in all ouhers, because God cherishes it and chooses to make it so, not because God had no alternative. ${ }^{36}$

David Griffin critically discusses and rejects the view that co-creative creatures are free because God voluntarily self-limits his own power. He recognizes that this "hybrid free will defense," as he calls it, is currently supported by such prominent theologians as John Hick, Emil Brunner, and L. Harold DeWolf. ${ }^{37}$ To this list must be added Arthur Peacocke, ${ }^{38}$ John Polkinghorne, ${ }^{39}$ Nancey Murphy, ${ }^{40}$ Ian Barbour, Diogenes Allen, and many others who accept Process Theology's emphasis on God's inclusiveness, temporality, sensitivity, affective capacities, persuasiveness, and causal efficaciousness, but who are reluctant to call themselves Process Theologians because they think that Process Theology can make no place for creaturely freedom bestowed by voluntary divine self-limitation. Arthur Peacocke explicitly affirms panentheism, the allinclusiveness of God, and divine self-limitation, while deploring their historical association in the twentieth century with Process Theology, which he repudiates. ${ }^{41}$ Ian Barbour says that Process Theology is the best model of God available, while preferring God's voluntary self-limitation in creating co-creative creatures ${ }^{42} \mathrm{I}$ also wish to see God's voluntary self-limitation recognized as a legitimate minority perspective for Process Theologians, even if this implies that many of the technical distinctions in process orthodoxy must be extensively revised or abandoned, especially Whitehead's detailed analysis of the nature of temporal concrescence and its application to God, which few have previously questioned seriously.

\section{How Process Theology Can Affirm Creation Ex Nihilo}

Many temporalistic theists object to mainstream Process Theology's clear repudiation of the traditional Christian view that God created our universe out of nothing, ex nihilo, at some point in the finite past. They affirm instead that God created our universe out of the chaotic remains of some prior universe or cosmic epoch, which in turn was also created out the chaotic remains of some still earlier universe, and so on to infinity, because every finite actuality was partly created by and out of some prior actuality.

As David Griffin put it, "Creation of our particular world was not initiated by a creation ex nihilo, in the sense of a total absence of finite forms of actuality, but was a creation out of chaos, out of a less ordered realm of finitude." Integrated into Process Theology, the claim that every reality is created partly by and out of antecedent temporal realities (and partly by God) implies that our universe or cosmic epoch is just the latest member of an infinite sequence of 
antecedent universes that God created necessarily because God is necessarily creative, social, loving, and embodied in some universe-ad infinitum.

I wish to show that and how we can retain valuable process insights such as that God is necessarily creative, social, loving, and embodied in some actual universe and still affirm creation ex nihilo for our universe. Without relating his metaphysics to recent developments in scientific cosmology, Robert Neville, both a friend and a severe critic of process theology, has previously championed creation ex nihilo. ${ }^{44}$ However, most philosophical-minded Process Theologians have not been able to conceive of a way to get around the principle that all realities are partly created out of prior actualities and still preserve God's necessary creativity, sociality, love, and embodiment. I will show that and how it can be done quite successfully employing concepts that are quite readily available in contemporary Big Bang astrophysics and cosmology, and that reasons given by process thinkers for repudiating creation ex nihilo can be bypassed. In developing these points, I also hope to show how process thought can relate its insights to contemporary scientific Big Bang Cosmology, and that traditional process thought contains elements out of which a process understanding of creation ex nihilo can be constructed.

\section{i. A New Framework for Understanding Creation Ex Nihilo}

In answering the question "Is God Creator Ex Nihilo?" on the Process and Faith website, John B. Cobb, Jr. replies that "Whitehead knew nothing of the 'Big Bang' and thought instead of cosmic epochs evolving out of earlier cosmic epochs with no singularities involved. Process theology followed him." ${ }^{.45}$ Process thinkers have indeed followed Whitehead in affirming that our universe, our cosmic epoch, was created out of the ashes of some temporally antecedent universe, and that both universes belong within an infinitely prolonged series of created universes that collectively fulfill the necessity of divine creativity, sociality, love, and embodiment. Charles Hartshorne affirmed, admittedly with some hesitation,

That actuality is finite in space I readily believe. It is certainly finite in some respects; for to say otherwise would be to say that everything thinkable was also actual, and this is absurd. But the serious question concerns the past of the creative process. Is there an actually infinite regress of past stages-if nowhere else, then at least in the divine becoming? If not, how can a first stage be either avoided or made intelligible, if every experience must have antecedent objects...? So Kant's first antinomy, his most potent argument, stares us in the face. All I can see to do is to reject his disproof of the possibility of an actual infinity.... This question I cannot at present answer to my own complete satisfaction. ${ }^{46}$ 
Hartshorne elsewhere fleshes out his cosmology of finite space and infinite time by linking it to Whitehead's doctrine of cosmic epochs, telling us that "I incline to Whitehead's view of cosmic epochs, each with its own laws." ${ }^{34}$ Presumably all of this means that a series of spatially finite cosmic epochs extends infinitely into the past, and that our universe was created out of the remains of the preceding epoch. The same interpretation must also be placed upon Lewis Ford's "Alternative to Creatio Ex Nihilo," which affirms: "For if the world is not created from nothing, it can possibly have an infinite past. If every creative act creates itself out of past acts, ad infinitum, the world must have an infinite past" ${ }^{\text {"48 }}$ and upon Cobb and Griffin's "Process theology rejects the notion of creatio ex nihilo, if that means creation out of absolute nothingness. Process theology affirms instead a doctrine of creation out of chaos." ${ }^{\prime 49}$ Griffin positions this chaos within a temporally ordered set of oscillating universes, explaining that "There was no beginning. The chaos from which our world began can be considered the final state of a previous world. Creation is the gradual bringing of order out of chaos." ${ }^{50}$

How does all of this relate to what is going on in contemporary scientific cosmology? Today, for the most part, cosmology is being done by astrophysicists rather than by philosophers or theologians. As seen in earlier chapters, most of these scientific cosmologists do not believe in God and seem to know little or nothing about process philosophy. They wish to leave the impression that their atheistic cosmological speculations are somehow "scientific," although this is far from being the case, as later explained. Still, for convenience, let us call cosmological speculation being done by astrophysicists and other professional scientists "scientific cosmology."

Contemporary scientific cosmology is very diverse. The variety that best correlates with the views of mainstream Process Theologians is Oscillationism, even though process thinkers have not explicitly affirmed it by using the word "Oscillationism." As explained in Chapter Four, contemporary scientific Oscillationists usually affirm that our universe is but the most recent in a temporally infinite series of cosmic epochs, that it was created entirely, not by God, but by an influx of energy from an antecedently existing universe, that this prior universe originated from its own Big Bang, enlarged to the maximum allowed by the tension between the expansive kinetic energy of its Bang and the constrictive force of its gravity, began to contract after gravity ultimately prevailed, and finally ended in a Big Crunch, from the ashes of which our own Big Bang rebounded.

Most scientific Oscillationists also affirm that the series or set of Bang-toCrunch epochs extends infinitely into the past. They do so primarily because they think that this is a way of avoiding God. As Alan M. MacRobert recognized in Sky and Telescope in 1983, "The idea of an oscillating universe, in which the Big Bang resulted from the recollapse of a previous phase of the 
universe, gained currency merely because it avoided the issue of creation, not because there was the slightest evidence in favor of it."

The naiveté of the view that an infinitely prolonged natural or spatiotemporal order of things needs no God would be readily apparent to philosophers, from Aquinas to Whitehead and beyond, who understand that an infinitely prolonged universe or set of successive universes would likely lack the complete self-sufficiency essential for naturalistic atheism and would be contingent upon God in many respects. For instance, God could and most likely would be required by each cosmic epoch to squeeze out any residual entropy or chaos inherited from an antecedent epoch, to select desirable laws (especially lifesupporting ones) for each new universe, and to choose its initial conditions (like the quantity of stuff, energy, or mass in the universe, the strength of the basic physical forces, and the asymmetry of matter over antimatter-or vice versa). Process thought would add that God is essential to provide each spatiotemporal occasion in every epoch with an "initial aim" that includes novel possibilities to be creatively actualized by the choice or initiative of every creature, and that God preserves and cherishes forever in his faultless memory the values created by existing individuals in each cosmic epoch and gives them "objective immortality."

Pure Oscillationism, which affirms a single infinitely prolonged strand of successive universes, has some stiff competition in contemporary scientific cosmology. The main competition comes from the many.worlds view, or what I call "Big Fizz Cosmology," according to which both time and space are infinitely extended and creative. Space in today's astrophysics is not just nothingness or an empty Newtonian or Kantian form that separates physical objects and processes. As Whitehead recognized, a lot is going on in so called "empty space" 52 Actual occasions constantly occur there, but they do not consolidate into persisting societies.

As documented in earlier chapters, today's cosmologists are convinced that space itself is a kind of physical something, a field with its own physical properties, its own actualized mass/energy and density. It has a fine-grained foamy texture, best described by the laws of quantum physics; and it can be bent, stretched, shrunk, warped, vibrated, and knotted. The seemingly emptiest spatial regions are seething or bubbling with "virtual particles" awaiting birth or actualization. Scientific-minded cosmologists think that quantum indefiniteness allows these virtual or real potential particles to be converted briefly into actual particles, so long as they promptly cease to exist so as not to violate-for more than an instant-the principle of the conservation or constancy of energy

Matter and antimatter particles are constantly being created in empty space; usually they annihilate one another almost immediately, but perhaps not always. The cosmology proposed by highly influential Inflation Theory says that effervescent virtual particles occasionally escape from "empty space" into more enduring actuality, as allowed by the random fluctuations recognized by quan- 
tum theory, and then they inflate into entire universes. This happens more than once; most Inflation Theorists think that it happens an infinite number of times to actualize every possible world. Process thinkers should agree here with Hartshorne (and Leibniz) that the notion of actualizing every possibility is absurd since there are incompossible possibilities within and between every conceivable world. Quantum Cosmologists seem to think that every possibility is actualized, even if it takes an entirely new universe to accommodate each one. Process thinkers dissent, however, on the grounds that for moral and aesthetic reasons, God would not create the innumerable horrible, trivial, or boring worlds that are logically possible.

Our spacetime system, the only one we can observe directly (at least in part), the one whose origins we can trace back to a chaotic Big Bang, originated around 15 billion years ago. All events that compose our spacetime system are causally connected with other events within that system, which is in principle traceable back to the Big Bang. The cause of the Bang itself lies outside our spacetime system; it is transcendent; but it may or may not have been God.

Most Quantum Cosmologists, those who apply quantum theory to quantum questions, hold that our universe is but one of infinitely many universes spawned, not by God, but by and from the near-nothingness of quantum-foamy empty space. According to this many worlds Big Fizz inflationary scenario, the relevant infinitely fertile "empty space" is not a part of, does not belong to, our cosmic epoch. Big Fizz Cosmology postulates a transcendent quantum-fizzy Motherspacetime or Superspacetime within which infinitely many child-worlds or universes co-exist in infinitely extended space throughout infinite time. After child worlds are thus spawned, they may or may not then begin to oscillate

Let us consider the "many worlds" notion of infinite Superspace that supposedly accommodates an endless number of independently co-existing and spontaneously conceived child universes to see if it can help us to conceive of creation ex nihilo. According to cosmological theories widely accepted today, since infinite Superspace has always existed, it co-exists with infinite Super time. When a spatiotemporally finite universe like ours expands, it pushes into pre-existing Superspacetime, not into absolute nothingness. We have seen that many scientific-minded cosmologists take all of this stuff very seriously!

Developments in contemporary cosmology outlined thus far may strike you as utterly wild speculation, having little or nothing to do with empirical natural science, even if it originates with professional astrophysicists. Indeed, it is just that! All postulated antecedent and contemporary universes, and the infinite Supertime and quantum-foamy Superspace within which they are located, transcend our cosmic epoch and are totally inaccessible to human experience. They exist before and beyond our spacetime system in a time prior to the beginning of our time and in a space beyond and outside of our space, so we can never observe them. They are supernatural realities, if real at all, that transcend our system of nature or spacetime. If they exist, they are supernatural other 
worlds. Even science, if this is science, cannot get along without the supernatural. As philosophical postulates or explanatory hypotheses, their reality (or lack thereof) can be considered and debated-as was done in Chapters Three through Nine. Obviously, any explanatory appeal to realities that transcend our spatiotemporal natural order of things always leaves empirical natural science far behind. Hereafter, "scientific" cosmology will appear in quotes.

So, what does this have to do with creation ex nihilo? The concept of transcendent Superspacetime developed by Big Fizz Cosmologists is purely theoretical and has nothing to do with verifiable natural science, but it may nevertheless be extremely useful to theologians! I began by saying that Process Theologians have been unable to conceive of how to make sense out of creation ex nihilo and still affirm infinite Divine creativity, love, sociality, and embodiment. This is largely because they assumed that finite space is the only possible complement to infinite time. Hartshorne, for instance, says that "The divine actuality so far as I can grasp the relevant concepts, must involve a numerically infinite number of past creatures, but the creation need not, and I think must not, be spatially infinite", ${ }^{33}$ and he repeatedly asserts the finitude of space while affirming the infinity of time. ${ }^{54}$ By default, if in no other way, other Process Theologians seem to agree.

What would happen if, contra Hartshorne, the conceptual framework of process theology were expanded to include not only Hartshorne's infinite Supertime, but also the infinite Superspace postulated by so many contemporary "scientific" cosmologists? Here, our objective is simply to extend our way of conceiving of the arena of infinite Divine creativity, love, sociability, and embodiment; and this has nothing to do with verifying propositions about other transcendent worlds, which we mortals could never do. Neither infinite Supertime (previously assumed or affirmed by Process Theology) nor infinite Superspace (hitherto denied by Process Theology) are verifiable by us. Only God could do the job.

Within infinite Divine Superspacetime, God could be infinitely loving, social, embodied, and creative without being tied to a single temporal strand of spatially finite antecedent-and-successive universes. Within infinite Superspace and throughout infinite Supertime, God could create many co-existing universes out of nothing, or nothing more than "empty" Superspace itself; and God could be infinitely creative, social, loving, and embodied in relation to them. No coexisting universes would have to be created out of antecedent universes, although some might be. As God wills, some or all co-existing universes could be completely independent causally of all the others, so the crucial barrier between mainstream process theology and traditional Christian theology would no longer exist.

Divine creation of universes ex nihilo, thus understood, always presupposes other actualities, that is, God's embodiment somewhere in Superspacetime, but actual universes or Divine bodies need not be created out of other 
actualities, such as temporally antecedent universes. Process Theologians can consistently affirm that throughout everlasting Supertime, God may create, as willed, many independently existing universes out of nothing, or the nearnothingness of "empty" Superspace; and if, once initiated, some universes form an oscillating series, this is not true of our universe, which God could have created ex nihilo.

In infinite Superspacetime, all child universes could be so far removed from every other-infinitely far apart if necessary-that they could never contact or causally influence one another or be derived causally from preceding universes. Or, if God wills, some might have tangential contacts with others, being connected perhaps by wormholes or creative acts of God. Some of these coexisting child universes might even be Heaven, Purgatory, or Hell; and God might be able to figure out how to get us from one to the other! "Beam us over, God!" After we die, God could just reconstitute us in transformed and much improved resurrected bodies (as John Hick suggests) in the spacetime of another world that co-exists with our universe in infinite Superspacetime. Again, the point is just to conceive of such things, to make them intelligible, not to verify or confirm any beliefs we may have about them.

The concept of infinite Superspacetime is neither the Newtonian notion of absolute space and time, nor Einsteinian relativity spacetime. It derives not from classical or relativity physics but from quantum physics applied imaginatively to cosmology. My suggestion that God might recreate an improved edition of us in another co-existing spacetime system is not as un-Whiteheadian as it may seem. If order as we know it is usually a complex emergent achievement from pre-existing order, this could not be true of creation ex nihilo; and even if true, in light of what quantum physicists have discovered about non-local causality, we can no longer assume that all causal influence requires spatiotemporal contiguity or proximity. The telepathy in which Whitehead believed ${ }^{55}$ does not presuppose that. According to quantum physics, what Einstein called "spooky action at a distance" is a reality; and within Superspacetime, that action could transcend local universes. Whether it actually does or not, we do not know.

If God is actualized in both infinite Supertime and infinite Superspace, the everlastingness of divine sociality, love, and creativity would not be subverted if a finite universe like ours was created out of nothing about 15 billion years ago. Why should God's everlasting creativity be tied to a single temporal strand of spatially finite universes, of which ours is the most recent member? God could be everlastingly creative in Superspace as well as in Supertime, where particular universes need not emerge from antecedent universes. To reconcile Process Theology with the creation of our universe ex nihilo, we need a concept of Divine Superspacetime as God's sensorium and arena for infinite creativity, as further explained in the following discussion. If my analysis is successful, Process Theology should adopt the view that God's potential embodiment is coextensive with infinite Superspacetime; and God's actual embodiment is 
coextensive with all the worlds God has chosen to make within Superspacetime. God's present body is not confined to our finite Big Bang spacetime epoch, which may or may not have antecedents, depending on the plausibility of Oscillationism.

Taking the general concept of Motherspacetime or Superspacetime from contemporary many worlds Big Fizz Cosmology does not and should not commit Process Theology to much of the unwieldy baggage often attached to it. Process thinkers will want to reject the Principle of Plenitude, so popular with today's "scientific" cosmologists, according to which all possible worlds are actual worlds. Instead, in infinite Superspacetime, God creates all the worlds that he chooses, but not all possible worlds. For many good reasons, God is not driven by the ideal of Plenitude, which requires the creation of all possible worlds. God may have created an infinite number of worlds in Superspacetime, but God understands that infinity cannot be used up and that an infinite number will always remain to be created. God also realizes that many possible worlds are too horrible, or too trivial and boring, to be created at all. As Whitehead noted, "It is not true that God is in all respects infinite. If He were, He would be evil as well as good." 56 Divine Superspacetime need not be conceived as resembling the quantum-foamy spacetime of our universe, in which actual particle-occasions are constantly emerging spontaneously but briefly from virtuality. Instead, Superspacetime is God's arena for deliberate but selective creativity; and it has all the properties that God wants to give to it, even though we may not know what they are.

Mainstream Process Theologians were unable to conceive of creation ex nihilo because they were wedded, implicitly if not explicitly, to the model of a single strand of spatially finite oscillating universes extending infinitely into the past, each member of which arises causally from both God and from its immediate predecessor. Hartshorne affirmed "an infinity of earlier universes, each produced out of its predecessor, more or less catastrophically or gradually;" but God created them all, including our universe, out of their predecessors. ${ }^{57}$ This cosmological model precludes the possibility that a universe could arise causally only from God at some point in the finite past-the essence of creation ex nihilo. It assumes that God's infinite creativity was only temporally ordered; but it may also be spatially ordered as Divine Superspacetime, where God might be everlastingly creative of multiple universes that have no causal relations with our system of spacetime; and our system of spacetime could arise directly from God's Superspacetime and creative will alone, without being preceded by antecedent universes. Other universes or cosmic epochs could be "beyond" ours spatially, to use Whitehead's word for it, without being "before" ours temporally, as mainstream Process Theology has assumed. 


\section{ii. Elements of Superspacetime in Process Thought}

Elements out of which a theory of Divine Superspacetime can be constructed already exist in Process Theology. In discussing the possible existence of many independent worlds in an essay in Science and Philosophy, Whitehead proposed that and how we might conceive of independently existing universes that have no causal, temporal, or even spatial relations with one another.

We can imagine that, in the realm of existence, there may be an alternative space-time process other than that of nature; but nature and the alternative process do not conjoin to make one process. In fact we are aware of such alternative processes in dreams, where we apprehend a process of events which in respect to nature are nowhere and at no time. ${ }^{58}$

Despite any philosophical problems we might have with Whitehead's dream world analogy, this shows that historically the idea of multiple independent worlds is not entirely alien to process thought. The most effective and trouble-free way to conceive of independent worlds and to relate process theology to contemporary Big Bang Cosmology is to think of other worlds as coexisting, not in dreams, but within Divine Superspacetime, within which some worlds (like ours) could be created deliberately out of nothing, that is, out of the real potentiality and virtuality of genuinely "empty space."

Whitehead was unaware of Big Bang cosmology, as Cobb indicates. Hartshorne, by contrast, was well aware of it; but he neither made a serious and detailed attempt to relate his cosmological commitments to it nor verbally affirmed Oscillationism. However, he clearly had a concept of Divine Supertime, that is, of God's time before (and after) our time, the time of our fifteen billion year old universe. He wrote that:

Certainly someone ought to correlate metaphysics and physics. For instance, even if the supreme reality is a kind of becoming, then it seems there must be a sort of divine time (even Barth says something like this), and the correlation of this with worldly time, as construed by relativity physics, is a neglected and apparently extremely formidable task. Perhaps this is rather a problem in cosmology than in pure metaphysics, cosmology being the application of metaphysical principles to what science reveals as the structure of our "cosmic epoch." Yet unless either physicists or metaphysicians have erred, there must be an at least possible way of harmonizing what the physicists say is true of our cosmic epoch and what metaphysicians say is true of all possible epochs. ${ }^{59}$

As we have seen, today's "scientific" cosmologists do not restrict themselves only to our epoch, but this just makes them metaphysicians in disguise. 
I suggest that today's metaphysical (and only pseudo-scientific) cosmologists have done Process Theologians a great service in providing us with a concept of Superspace to complement the Supertime that Hartshorne and mainstream Process Theologians postulate to accommodate antecedent cosmic epochs.

Superspacetime is the proverbial transcendent space beyond our space and time before our time. Although the concept of Superspacetime originated with infinitely many worlds atheism, it can be united with the process concept of God to form the notion of a Divine Superspacetime, within which both infinite divine creativity and universes created out of nothing are possible and conceivable. If time and space are inseparable, as process thought and contemporary physics both suggest, then divine Supertime, affirmed by Hartshorne, also implies divine Superspace. Divine Superspace can be more inclusive than the finite space of our own and preceding oscillating epochs; it can embrace other co-existing universes.

Hartshorne likely had only the spacetime of our cosmic epoch (or similar antecedent oscillating epochs) in mind in insisting upon the finitude of space. If so, his insistence on the spatial finitude of our cosmos in no way conflicts with affirming infinite Superspacetime as the ultimate arena for divine creativity. As far as I have been able to determine, Hartshorne does not give a good argument for his insistence that space must be finite. He just affirms spatial finitude without argument, as if it were intuitively certain or obvious, which it clearly is not to contemporary "scientific" cosmologists; but his writings were never informed by the concept of Superspacetime that they have developed.

A good argument for the finitude of our space can be given, namely, at or immediately after the onset of the Big Bang, the space of our universe began as finite (slightly larger than a singularity); it has since expanded at a finite rate (the Hubble constant or cosmic expansion rate, plus perhaps a brief exponential but still finite inflation rate); and the expansion has endured for only a finite amount of time (about 15 billion years). From these premises we can conclude that our space is finite. A parallel argument shows that our time is finite and has a "first moment"; but this is perfectly compatible with the idea that our finite spacetime exists within and is expanding into the "empty" quantum-foamy virtuality of infinite Superspacetime, which has no "first moment."

We might conjecture, as suggested to me by Lewis Ford, that Hartshorne would argue for the finitude of space by appealing to the premise that there can be no actualized infinities at all, that such things are unintelligible, from which we could conclude that there can be no actualized infinity of space, that space is finite. Yes, but when reflecting on the far distant past, Hartshorne bites the bullet and reluctantly admits that process thinkers must affirm an actual infinity if they hold that each creaturely event is created out of some other creaturely event-ad infinitum; otherwise one must affirm creation ex nihilo! ${ }^{60}$ In these passages, Hartshorne clearly affirms an actual, not just a potential, infinity of past events for our world and for God. Anyone who wants to avoid creation ex 
nihilo is logically committed to an actualized infinity and thus must repudiate the above argument that space is finite.

As quoted earlier, Cobb says that Process Theologians accept Whitehead's notion of distinct "cosmic epochs." Whitehead invented this terminology, though he was not very specific about its scope. Under the influence of early quantum theory in the 1920s, Whitehead thought that our own cosmic epoch is dominated by electromagnetic energy that exists only in discrete quanta. He defined a "cosmic epoch" as "the widest society of actual entities whose immediate relevance to ourselves is traceable." ${ }^{\prime \prime 1}$ Our present cosmic epoch can be traced "to an aboriginal disorder, chaotic according to our ideals," ${ }^{26}$ Whitehead believed; but there are other cosmic epochs "far beyond our immediate cosmic epoch" that are ordered very differently from our own. ${ }^{63} \mathrm{He}$ knew nothing about Big Bang Cosmology, which was still in its infancy when these words appeared in Process and Reality in 1929; and he did not explain whether his "beyond" is to be construed spatially, temporally, or both. Mainstream process theology has interpreted Whitehead's wording temporally; but "widest" and "beyond" are actually spatial words, not temporal words; he did not say "oldest" or "before."

Perhaps Whitehead spoke better than he knew! Or perhaps he knew about Superspace as well as Supertime! Isn't it just his "extensive continuum" construed not simply as the realm of "real potentiality" for our own cosmic epoch, but "in its full generality beyond the present epoch"? ${ }^{64}$ Notice especially his emphasis on potentiality. The in-depth explication of Whitehead's concept of "extensive continuum" by Jorge Luis Nobo is almost perfectly compatible with the understanding presupposed here. ${ }^{65}$ Whitehead distinguishes this more general extensive continuum from that of our own epoch, which is dominated by societies of electromagnetic occasions. ${ }^{66} \mathrm{He}$ describes it as

...a vast nexus extending far beyond our immediate cosmic epoch. It contains in itself other epochs with more particular characteristics incompatible with each other.... We cannot discriminate its other epochs of vigorous order in our own epoch. This ultimate, vast society constitutes the whole environment within which our epoch is set. ${ }^{67}$

Whitehead uses the spatial word "beyond" rather than the temporal word "before" to refer to alternate cosmic epochs. He certainly does not say that our epoch's "whole environment" is merely temporal, as pure Oscillationism would have it. Co-existing universes in infinite Superspace are no more "traceable" by us than antecedent universes in infinite Supertime.

\section{iii. Process Objections to Creation Ex Nihilo}

As documented earlier, mainstream Process Theologians have clearly repudiated the traditional Christian belief in creation ex nihilo, and they have given a 
number of reasons for rejecting this belief. With one such reason I wholeheartedly agree, namely, the (Protestant) Bible teaches only that our universe was ordered out of chaos, but not unequivocally that it was created out of nothing. ${ }^{68}$ Let us begin with the reasons that John Cobb, Jr. gives in his Process and Faith website discussion of "Is God Creator Ex Nihilo?"

First, Cobb explains, the traditional theology of creation out of nothing reserves the word " "creation'... for a single act, the one in which the world is brought into being out of nothing." To this he opposes the process view that "God is creatively at work at all times and places." But these positions are not really opposed. Whether Cobb intends to make a historical point or a logical point here is unclear, but much of the hostility of mainstream Process Theologians toward creation out of nothing may issue from confusing historical associations with logical connections. It is true historicaily that traditional Christian theology tended to reserve the word "creation" for God's origination of our universe from nothing, but it did not deny that God is creatively at work at all times and places. It just used other words for God's ongoing creativity, words like "sustaining" the universe and exercising general and special "providence" over and within it.

Traditional concepts of God's sustaining and providential activities were usually qualified by the deterministic or predestinationistic assumption that everything that happens is implicit in creation itself from the very outset, or from the immutable vantage point of God's changeless eternity. Perhaps something like this is what Cobb has in mind. In their Process Theology: An Introductory Exposition, Cobb and Griffin raise this more subtle metaphysical objection. They tell us that the doctrine of creation out of absolute nothingness "is part and parcel of the doctrine of God as absolute controller."

Viewed logically rather than historically, creation out of nothing, ongoing creation, and the creation of co-creative creatures are in no way incompatible with one another. Creation out of nothing is logically contradicted by the mainstream process assumption of creation out of something, but not by the notion of God's ongoing creative activity within our world; and God's creating cocreative creatures is logically contradicted by the traditional notion of creating totally programmed non-creative creatures, but not by the notion of God's creating the universe out of nothing. No logical obstacles exist to combining creation ex nihilo with ongoing divine creativity and divine creation of cocreative creatures.

Cobb clearly wants to make a logical point when he says in "Is God Creator Ex Nihilo?" that "...the implication of the doctrine of creation is that God is quite external to the world and the world quite external to God." Closely related is Cobb's charge that creation ex nihilo encouraged "exclusive emphasis on divine transcendence."

Historically, Classical Theologians consistently affirmed God's immanence as omnipresence and made some solemn efforts to take this seriously; so 
it is not entirely true that Classical Theology made God and the world to be totally external to one another. The real difficulty is that what the Classical Theologians gave with one hand, they usually took away with the other. They did indeed characterize the contrast between God and the world so severely (pure being/pure becoming, pure cause/pure effect, spatially extended/incorporeal, and so forth) that the two were "quite external" to and mutually exclusive of one another. ${ }^{70}$

Does creation out of nothing inevitably involve such catastrophic contrasts? I can't see that it does. The opposition here is between our universe or epoch as caused by both God plus a series of antecedent worlds extending infinitely into the past, and as caused solely by God at the beginning of its own finite past. Both have God as a causal factor; the latter has only God. Necessary and everlasting Divine creativity, sociality, love, and embodiment presuppose the everlasting actualization of other universes somewhere in Superspacetime, but God's creative actualization need not be confined to a single line of temporally ordered and spatially finite cosmic epochs in Supertime, of which ours is the latest member. If, through either metaphysical necessity or God's voluntary self-limitation, the laws of quantum physics apply throughout Superspacetime and its products, and are not limited just to our spacetime and its antecedents, then every actualized universe is grounded in indeterminateness, spontaneity, and creativity, just as process metaphysics affirms. However, there is no logical necessity that "empty" Superspace be quantum-fizzy. A purely Newtonian Superspace is at least logically conceivable and thus possible.

In "Is God Creator Ex Nihilo?" Cobb himself recognizes that "the event in which our universe arose certainly seems to be markedly different from all the subsequent events"; and process metaphysics has its own ways of differentiating between God, the world, and occasions within the world without implying that God, the world, and finite occasions are "quite external" to one another.

As we have seen, some Process Theologians believe that God lacks the power to prevent evil, to work miracles, to create a universe out of nothing, or to bring about any effects where "persuasion" is not involved. " But must process thinkers presume that persuasive final causation applies absolutely everywhere? Might there not be some "markedly different" situations, for example, originating universes-creating the mass/energy out of which partly self-creative actual occasions emerge-in which God acts only as an efficient cause without being a final cause in the sense of giving initial aims to occasions that issue from pre-existing societies? Insisting that God, who has his own aims for newly created universes, must be able to persuade everything by imparting initial aims to successive occasions could not apply before the first moment of creation $e x$ nihilo. Before that, nothing exists to be persuaded; the first moment of creation out of nothing succeeds nothing. Beginning with the very first moment, however, something may exist to be persuaded. The absolutely original grandly unified and undifferentiated mass/energy presumed to exist at the very begin- 
ning of our Big Bang might not be susceptible to persuasion; but as soon as it is sufficiently unwound, expanded, and diversified to generate actual occasions, it would. We cannot simply equate physical energy with persuasive creativity; the basic physical conditions that make partly self-creative entities possible must come first. Dictating that persuasion must be exercised even on the non-existence that preceded our Big Bang is an irrational demand, like insisting that circles must be squared. Non-existence cannot be a co-creator with God; but from or very near the outset, a new universe created ex nihilo could be.

In his website discussion, Cobb relates the process view of infinitely prolonged ongoing creation to Big Bang Cosmology by indicating that the latter calls for an initial "singularity" from which our universe emerged, and by doubting that this means strictly "out of nothing." About this, at least four points need to be made.

First, singularities are defined as being infinitely small, dense, compressed, hot, and curved; an initial singularity has no magnitude or locus in our spacetime since that is what emerged from the initial singularity. Some versions of Big Bang cosmology really do affirm that our universe emerged from a singularity. Clearly, something infinitely small is absolutely nothing empirically and physically. Not even God could perceive something infinitely small, and nothing can be physical that is absolutely devoid of all spatial properties, having no size at all, because spatial extension is the very definition of the physical. As all modern philosophers agree, "All bodies are extended."

As noted earlier, initial singularities have many problems that make them cosmologically unattractive. In brief, being absolutely nothing empirically and physically is surely one of the most serious difficulties; another is that nonphysical things cannot be physical causes, so an initial singularity does not provide a physical explanation for the origin of our universe. Closely related is the problem that no one knows what would make a singularity explode because no known laws of physics apply to them. Again, cosmic epochs separated by singularities could not belong to a single, continuous, spatiotemporal, causal sequence because space, time, physical causation, and all natural laws break down completely and do not exist in or apply to singularities. Yet again, we could not reason back to singularities separating cosmic epochs, or to earlier epochs themselves, by extrapolating from the natural laws that we know because these laws presuppose spacetime for their application and terminate absolutely at singularities.

Second, Oscillation Cosmology is not bound inextricably to the idea that successive universes arise from and are separated by singularities. Many contemporary Oscillationists agree with Stephen Hawking that quantum effects would prevent a prior universe undergoing gravitational collapse from shrinking to a singularity. According to Big Bounce Oscillationists, a universe or cosmic epoch being terminated by a Big Crunch would rebound from a small finite state of intense compaction into a subsequent cosmic epoch initiated by a Big Bang 
without first proceeding all the way to total collapse into an infinitely condensed singularity.

As Cobb indicates, Whitehead thought "of cosmic epochs evolving out of earlier cosmic epochs with no singularities involved." Process Oscillationists would presumably find Big Bounce Oscillationism very congenial, for it requires no singularities between crunch/bounces. It has its own problems, as indicated in earlier chapters, but by appealing to it Process Oscillationism could affirm a Big Bang that rebounds from an antecedent universe without having to embrace troublesome singularities.

Third, our universe may not be derived from a singularity or a crunched-up antecedent cosmic epoch at all. If and when singularities form at the end of a Big Crunch, why don't they just stay there forever? No one knows what would cause a singularity to explode. No physical laws that we know could account for it, for all of them break down in singularities. The quantum fluctuations to which Inflationary Cosmology appeals would not do the job because they presuppose the laws of quantum physics, which, along with all other natural laws, would also break down in singularities. Inflationary Cosmology does not derive its many worlds from singularities or from crunched-up antecedent universes. Inflation requires just the right kind of quantum-foamy "empty space" in Superspacetime; and singularities and crunches just aren't the right stuff.

For the reasons just given, with or without singularities, Process Cosmology need not and should not give an oscillationistic account of the origin of our universe. The most plausible view is that our world or cosmic epoch was not created out of a preceding universe. Instead it was created out of nothing (without other-world antecedents) within divine Superspacetime. If our low mass universe is open, as it now appears to be, especially in light of the very recent revolutionary discovery that the rate of Hubble expansion is increasing, not decreasing as previously assumed ${ }^{72}$ then our universe does not belong within any kind of an oscillating series because all members of such a series must be closed to sustain infinite oscillations.

Fourth, Cobb doubts that the nothingness to which contemporary cosmologist appeal is really nothing. Although singularities are empirically nothing and have many other problems, what about the "empty space" of Superspacetime? Well, it is not a full-fledged antecedent universe, so we are at least that close to creation out of nothing. Superspacetime may but need not have the actualized quantum-foamy physical mass/density that contemporary cosmologists assign to "empty space" within our existing spacetime system; on no empirical or scientific grounds can we infer that Superspacetime is like our universe's quantum-fizzy spacetime "vacuum." It could be closer to a realm of real potentialities than to an actualized energy field. Aside from the co-existing universes that God has created, Superspacetime could consist mainly of potential rather than actual occasions; and nothing is to potentiality as something is to actuality. 
As the everlasting arena for creativity, Divine Superspacetime is God's infinitely extensive potency for creativity and social sensitivity. Its "spontaneity" is God's well-considered selectivity and creativity.

The actualized regions of Divine Superspacetime would contain, not all possible worlds, but only those universes deemed desirable by an infinitely loving Creator. Just how many co-existing worlds there are, if any, only God knows; but at least one universe must exist in perpetuity to satisfy God's loving, social, creative nature and the plausible requirement that all minds are embodied. Any number of successive and/or co-existing universes could come and go, given an infinite amount of time to play with them. Unlike us, God doesn't have to rush to do anything. Presumably, as many universes would co-exist as God freely chooses to be involved with; but only God knows how many.

The view proposed here does not locate God entirely outside of our cosmos. It allows for all the divine immanence that metaphysics and religion find desirable; but it recognizes, as do most Process Theologians, that God's Primordial Nature, comprised of the everlasting and omnipresent features of divinity, transcends our cosmic epoch. It also does not violate Whitehead's "ontological principle," according to which explanatory reasons are always located in actual entities, but not necessarily in actual occasions. ${ }^{73}$ God is not located in Superspacetime; rather, it is located in God, the ultimate all-inclusive actual entity, without whom there would be no space, no time, no actuality, no potentiality.

Finally, Hartshorne maintained very explicitly that the finitude of past time is inconceivable. After conceding that if we conceive of the past as infinite, what we could know of it is "negligibly small," he then argued,

Conceive of it as finite, and then it seems fairly clear that we never grasp what is meant by a first stage of creation, a process preceded by no process. All our thinking seems to break down at that point. We would have either an effect of an inconceivable cause, or something which simply transcended the causal idea, and hence our concept for explaining concrete things. ${ }^{74}$

In response, we must distinguish the finitude of our spacetime, which is conceivable, from the infinitude of Superspacetime. Creation of our universe ex nihilo does not presume an absolute "process preceded by no process." It presupposes the everlasting processing of Divine creativity, which need not be located solely in oscillationist Supertime but could be expressed in many worlds that either co-exist within and/or are created successively within Divine Superspacetime. If so, God's occasions or experiences of created worlds would always be preceded by other divine occasions or experiences, even if the series of occasions that constitute our world originated ex nihilo around fifteen billion years ago. The God of Process Theology can be both the final (purposive), efficient (creating ex nihilo ), and formal (the Divine vision of eternal objects) 
cause of a universe created out of nothing. If efficient causation acts from the past to the present, God's creative act of bringing our world into being out of nothing could be in God's past without being in our world's past. Creation ex nihilo is possible and conceivable without violating the "no process preceded by no process" principle from God's perspective, though it might seem so from a non-process-theism human perspective. If the "all creation" refers to Superspacetime, God could still be "not before all creation but with all creation"75 while definitely and necessarily existing "before" the creation of our spacetime system fifteen billion or so years ago.

Is it God as transcendent cause, or the world as an ex nihilo effect, that Hartshorne regards as inconceivable?

If God is everlastingly creative in Superspacetime, God's creation of our universe out of nothing would not be an inconceivable effect of "an inconceivable cause" because God, the cause, really is conceivable, at least in the abstract. Hartshorne has argued extensively and persuasively that we can and do have an abstract concept of God (the cause) without knowing God's full concreteness. The crucial issue is whether a universe caused by God alone is any less conceivable than a universe produced by God out of an antecedent universe. If God is conceivable at all, then a universe caused by God alone would not result from an "inconceivable cause." Perhaps it is inconceivable that a necessarily creative, loving, social, and embodied Supreme Becoming should exist without having created anything to love, but other universes in Superspacetime having no causal relations with our own epoch could fill that bill.

Hartshorne's main point could be that a universe created out of nothing would be an inconceivable effect. I contend, and I believe Hartshorne would agree, that the notion of causation as such is broader than that of physical, that is, spatiotemporal, causation. It is the notion of conditions that are either necessary and/or sufficient for producing an effect. Even if, contrary to the absolute incorporeality and timelessness of the classical God, all efficient causal conditions must be in some sense spatiotemporal, then the relevant spatiotemporality for creation ex nihilo could just be transcendent Divine Superspacetime; it need not be the spacetime of an antecedent universe from which our universe was causally derived. Our Big Bang could have been created out of nothing within God's Superspacetime without violating any defensible presupposition of Process Theology.

Thus, subtle and not so subtle replies can be given to the central objections that mainstream Process Theologians have raised against the traditional doctrine of creation ex nihilo. The preceding account of how Process Theology can accommodate creation ex nihilo may need a bit more tweaking and development here and there; but its affirmation would permit Process Theology to avoid alienating those more conventional Christians who are convinced that in the beginning, God created our universe out of nothing. 
In sum, with a few minor revisions, Process Theology is the most religiously viable and rationally intelligible option available to us today. It can be saved from some of its own mistakes like its contention that God cannot know us in our subjective immediacy, that God creates free creatures because creaturely creativity is a metaphysical necessity not a Divine voluntary self-limitation or choice, and that God could not and did not create our universe out of nothing.

Armed now with a better understanding of what it means to exist and a more viable concept of God, whether God exists and whether God caused the Big Bang can now be addresses more intelligibly. 